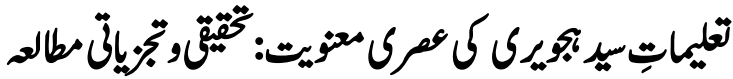

\section{The Teachings of Syed Ali Hujwiri and Contemporary Era}

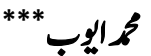

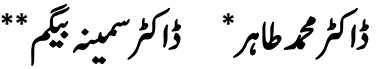 \\ ISSN (P) 2664-0031 (E) 2664-0023 \\ Received: April 3,2021 \\ Accepted: April 30, 2021 \\ DOI: https://doi.org/10.37605/fahmiislam.v4i1.229 \\ Published: June 30,2021
}

\begin{abstract}
There are few great peoples in the history whose contributions and achievements are continuously alive in the heart of peoples.in this great and honest peoples is Syed Ali bin Usman Hujwiri, who start his mission of preaching of Islam's truly message from Lahore, when he migrate from hijwair. He wrote many useful books on the spirituals life of Islam, but unfortunately these are lost. Although the $K A S H F-U L-M A H J O B$ is still alive in the history and people gain lights from it.

Syed Hujwiri discuss in detail the nature of human being in his teachings, according to him human are two type by nature one who accept the teachings and message of Islam by its own will and other who don't accept the message of Islam. The second type of people oppose Islam. According to him there are very necessary to reforms in our spirituals institutions by different aspects e.g. the criteria of head of institutions (sofi) and his followers must be checked. The institutions based on education and studies. Society needs to learn necessary skills which help Sharia's objectives. There are difference in manners and rasms. He also explain the terminologies of Tasuwf. Tasuwf is the second name of good and high values. Those who are high in morality actually are high in Tasuwf.

In this article I write the main theme about the teachings of Syed Ali Hujwiri (RA) and its importance and contemporary era.
\end{abstract}

Keyword: Teachings, values, spirituals.

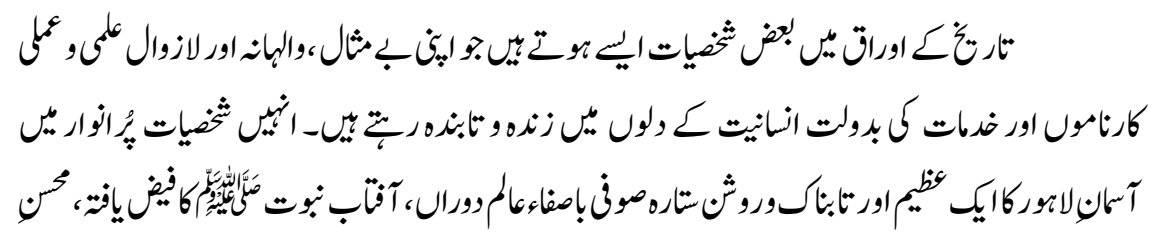

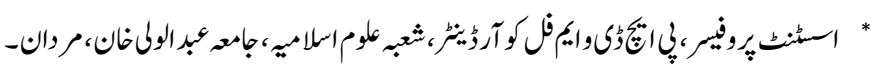

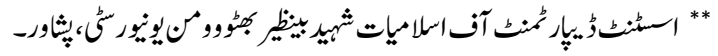

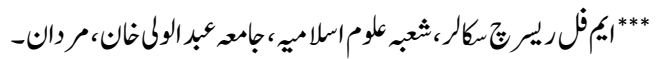




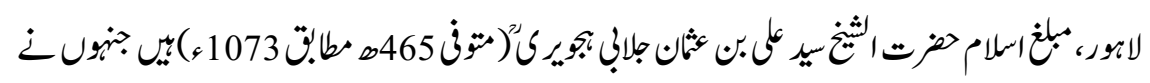

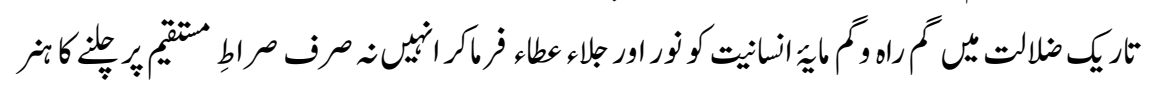

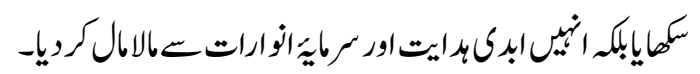

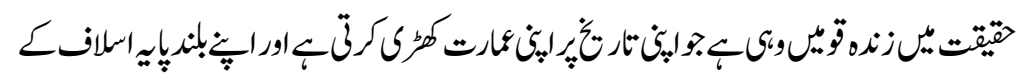

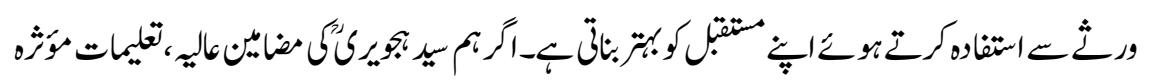

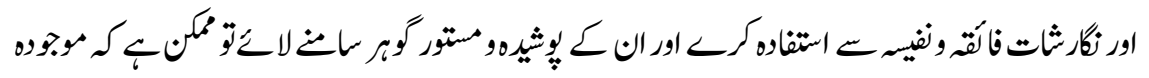

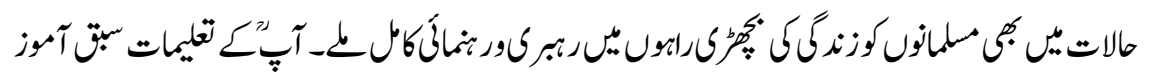

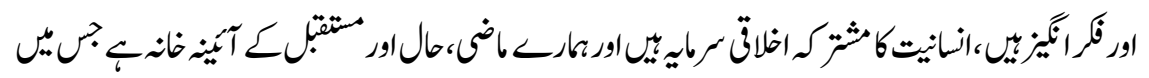

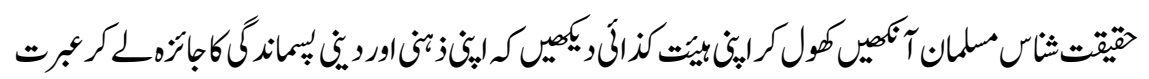

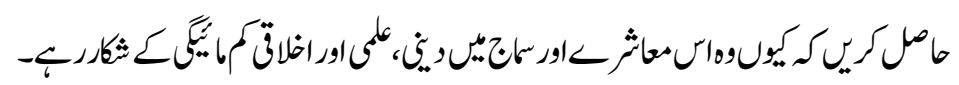

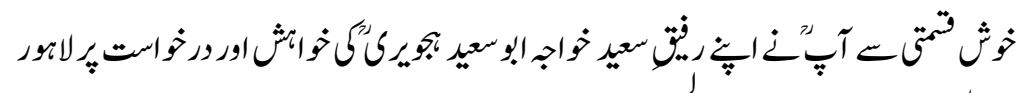

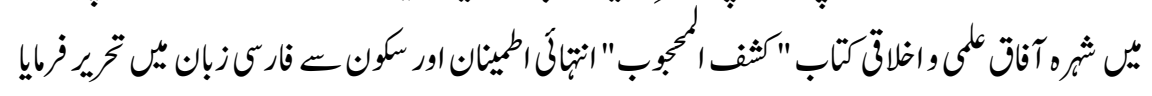

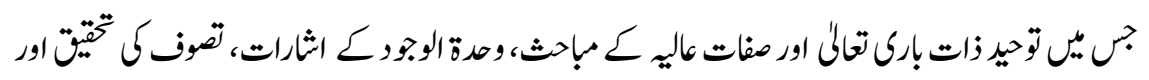

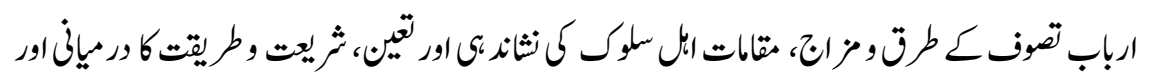

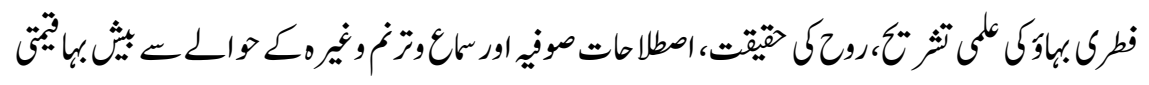

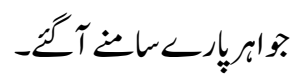

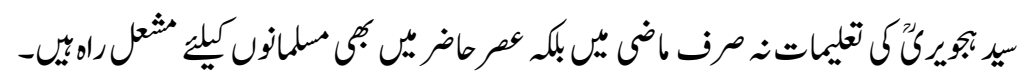

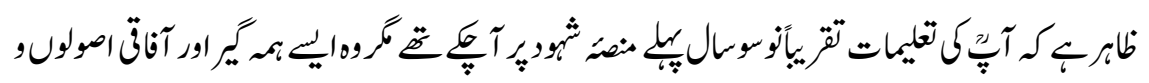

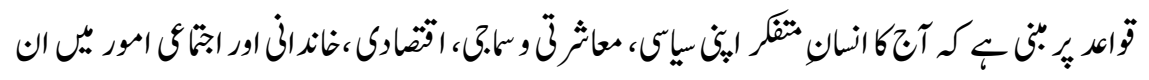

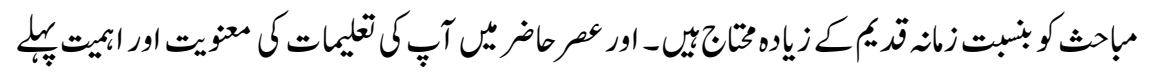

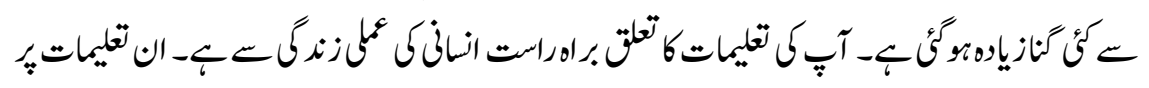

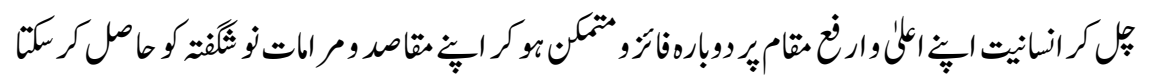

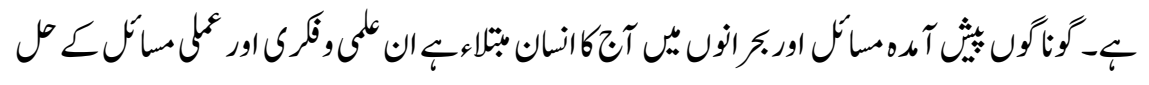




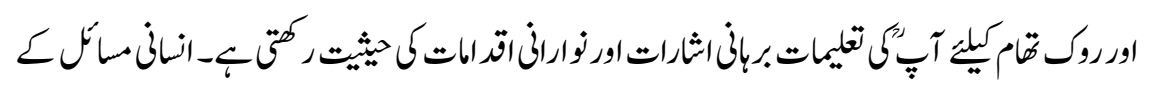

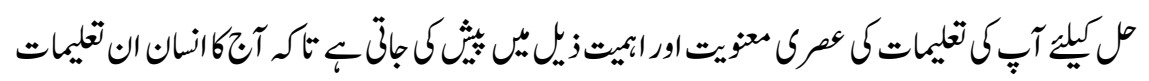

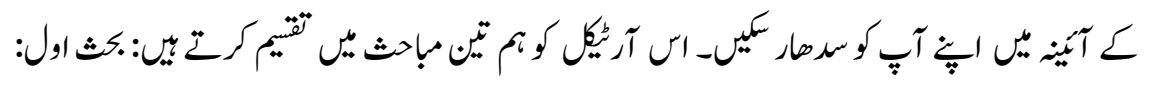

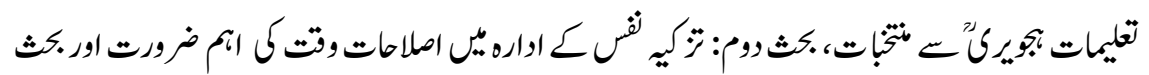

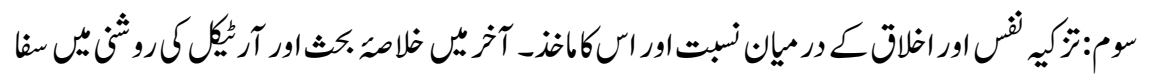

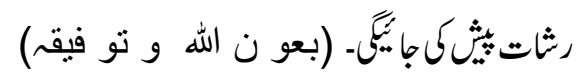

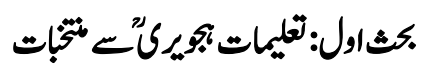

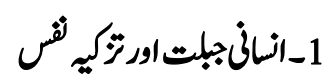

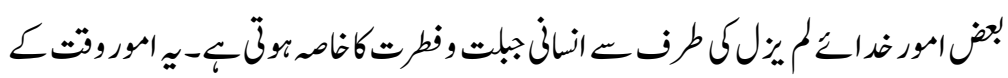

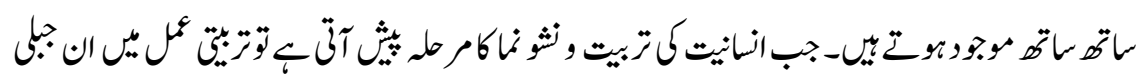

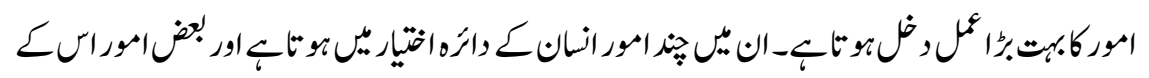

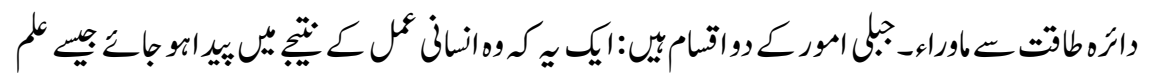

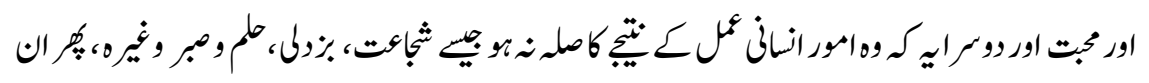

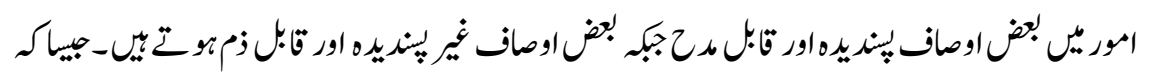

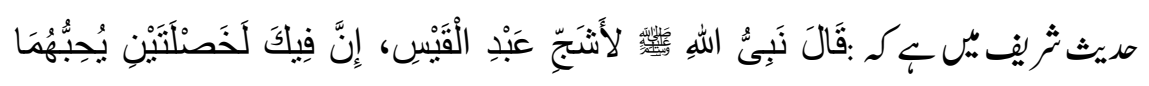

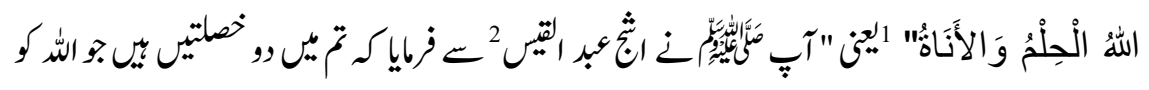

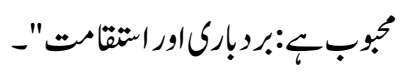

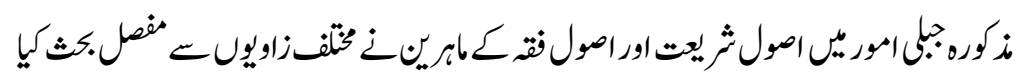

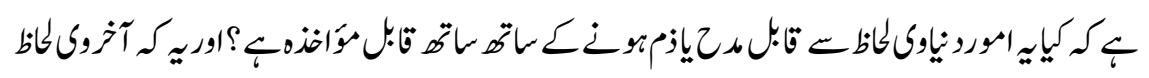

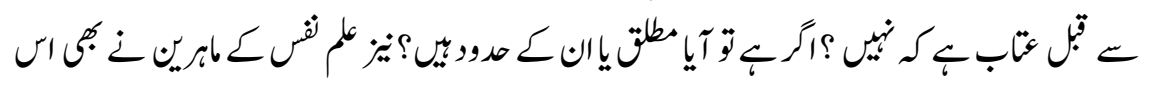

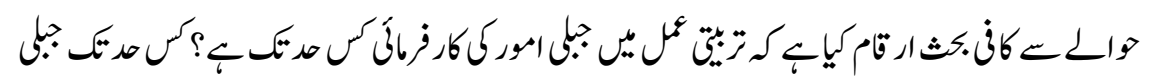

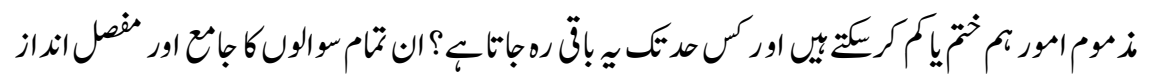

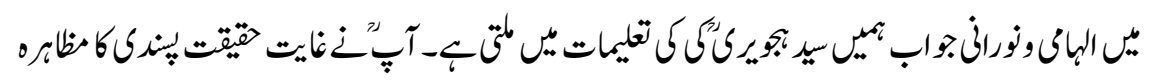




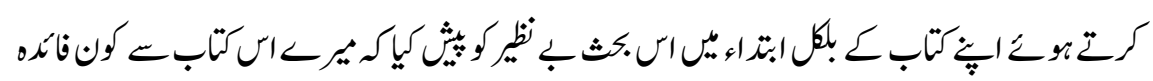

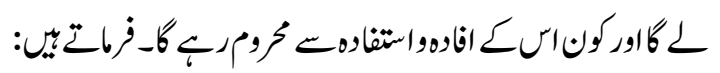

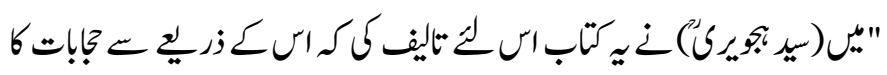

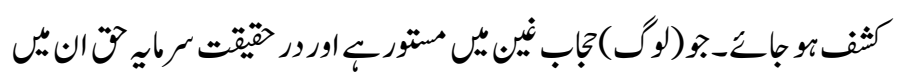

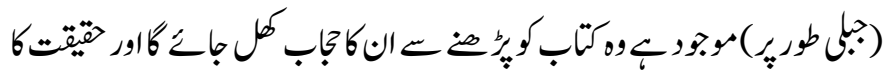

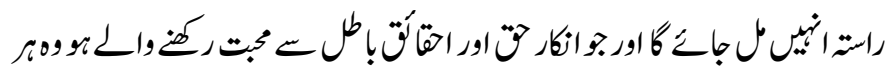

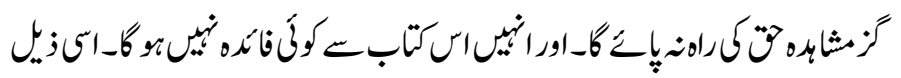

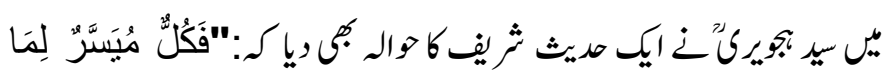

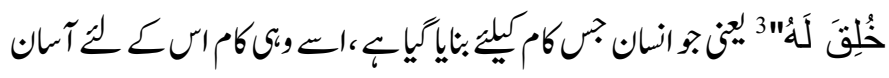

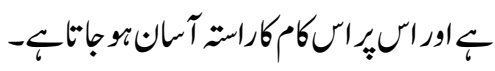
اورزاستيلكم:

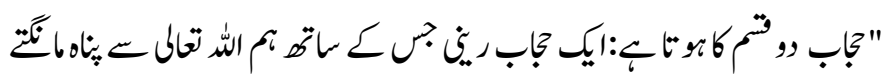

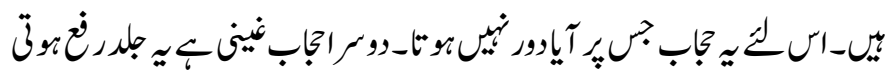

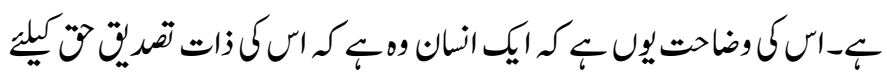

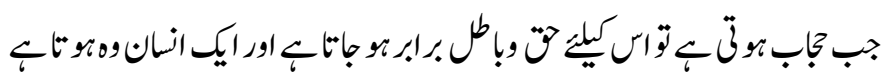

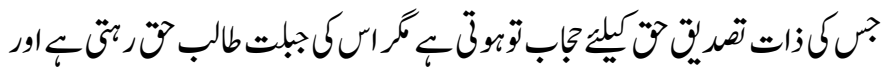

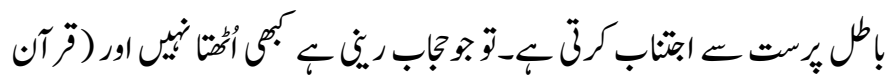

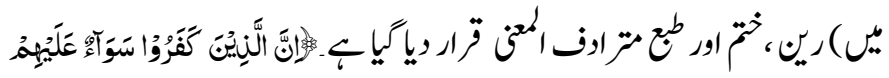

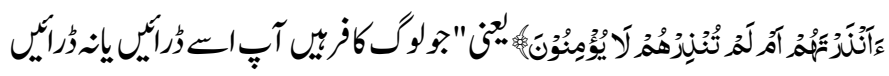

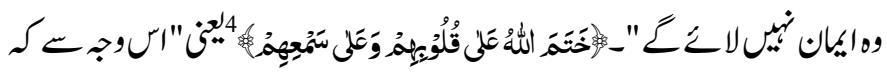

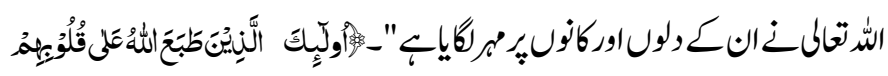

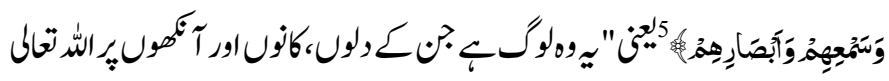




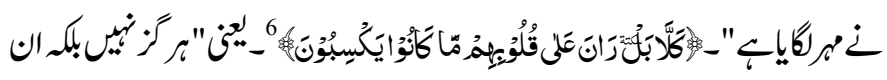

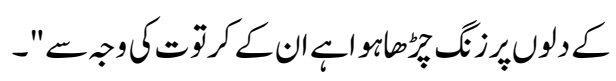

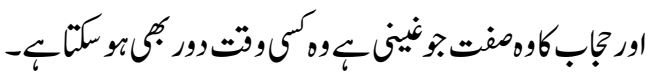

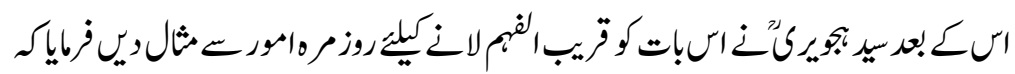

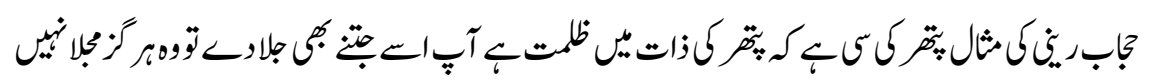

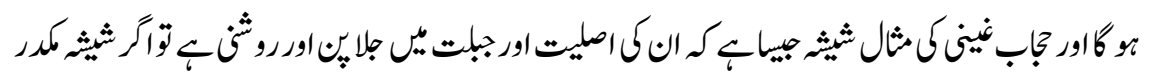

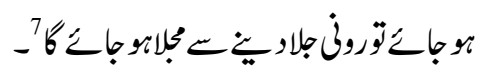

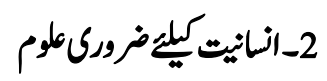

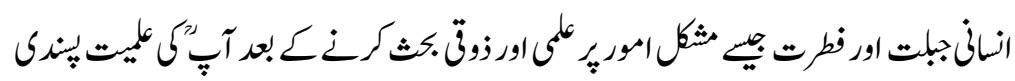

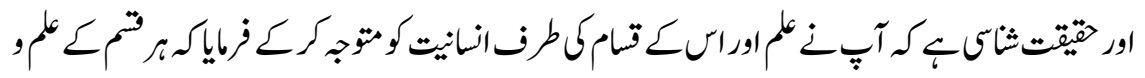

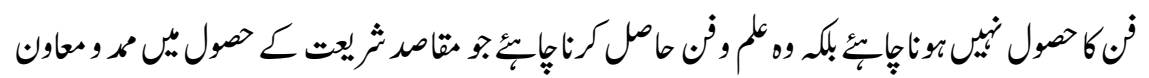

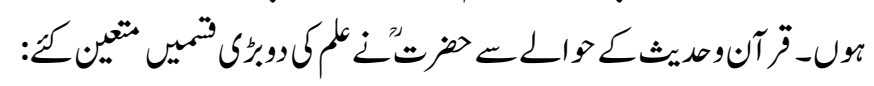

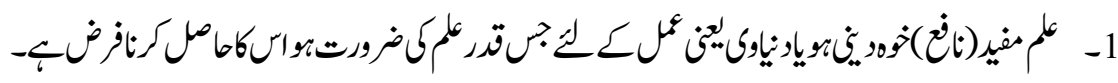

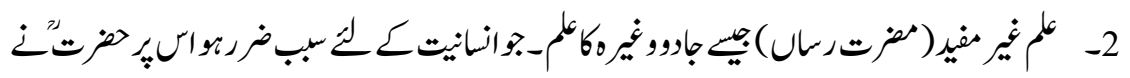

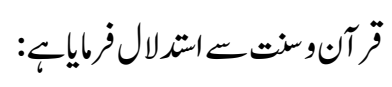

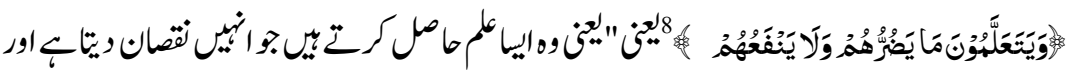

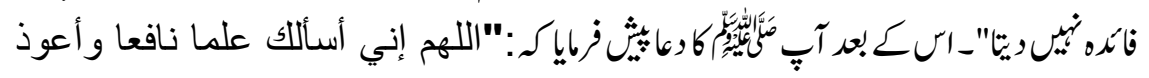

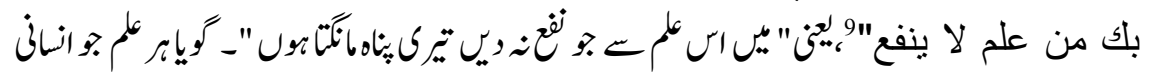

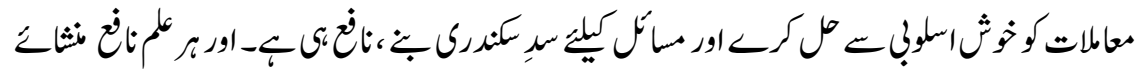

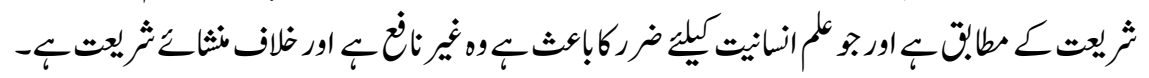

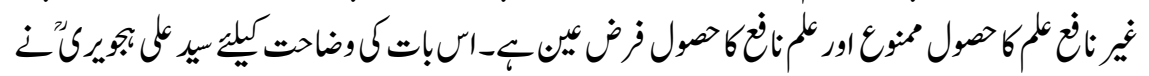

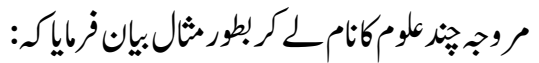
"جون علم نجوم وطب و علم حساب و صنعت بائح بديع و آنجم بدين ماند"10

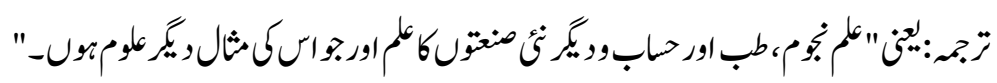




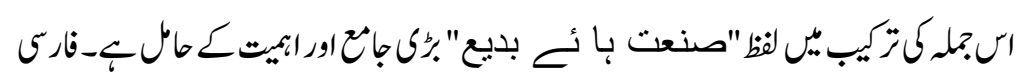

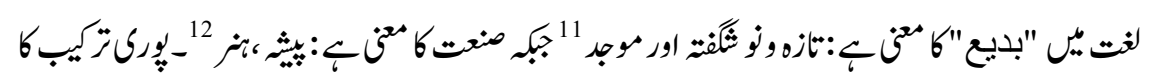

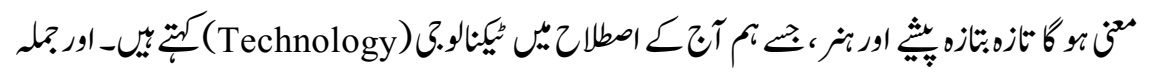

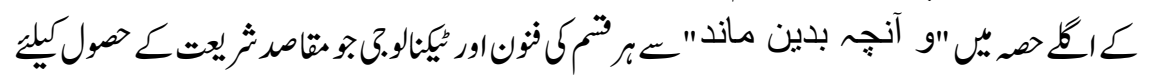

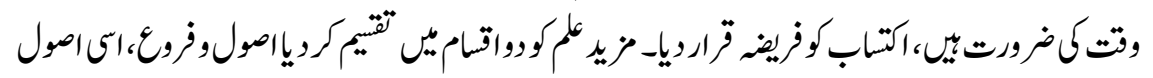

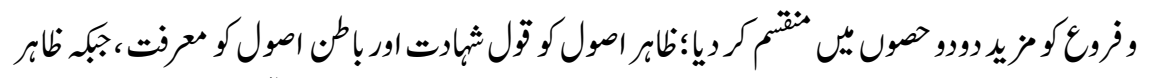

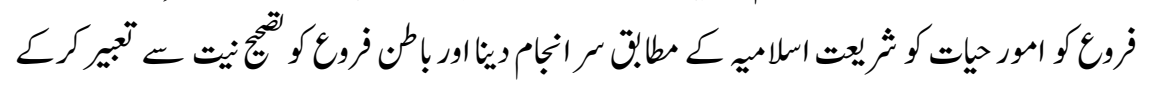

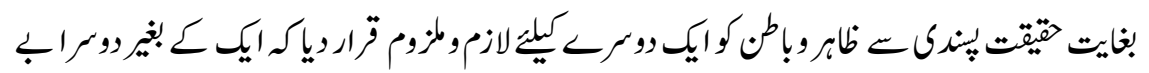

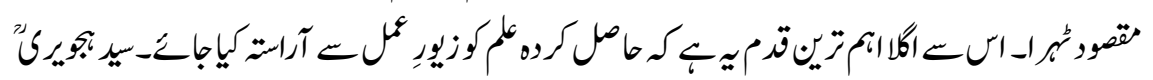

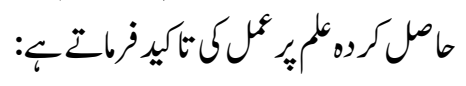

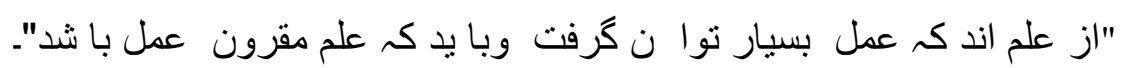

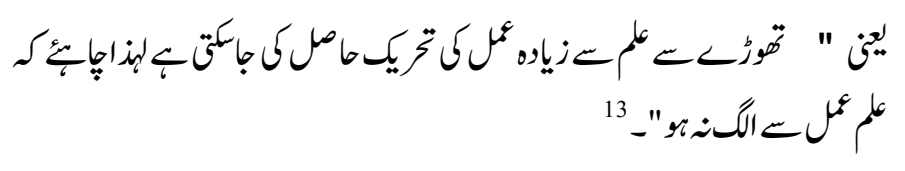

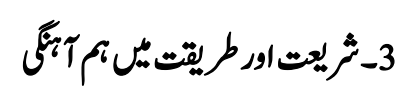

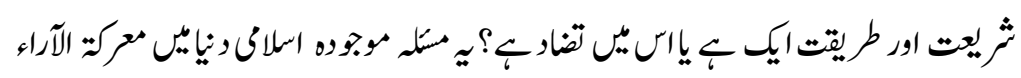

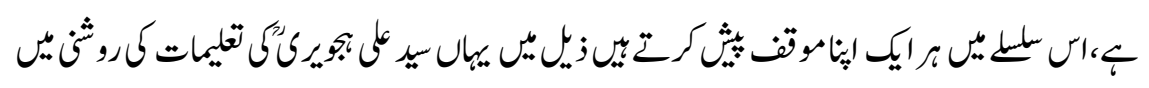

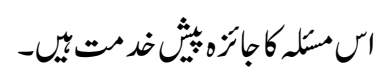

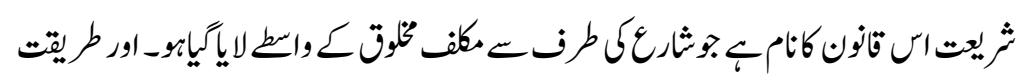

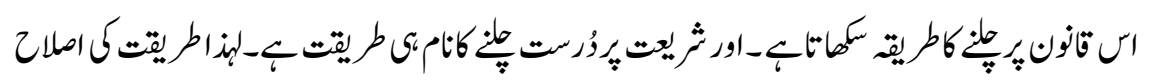

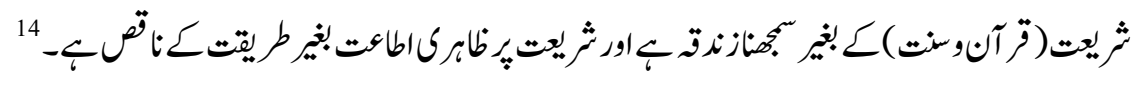

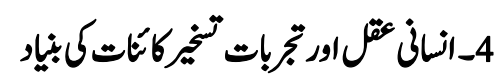




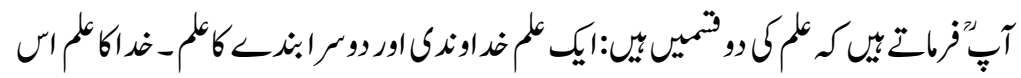

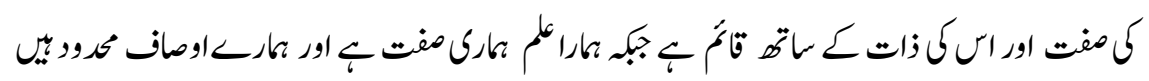

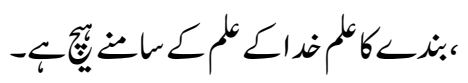

بس علم حقبقت را سـ ركن رعت است :يكى علم ب ذات خداوند

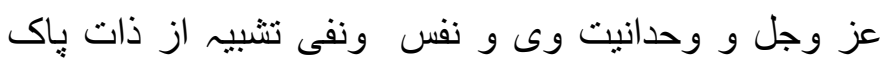

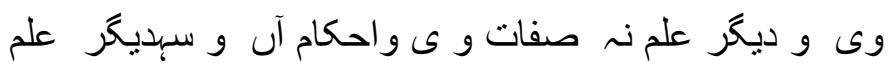

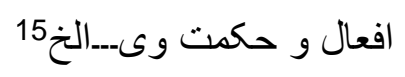

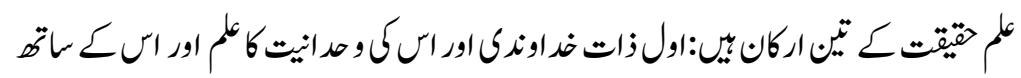

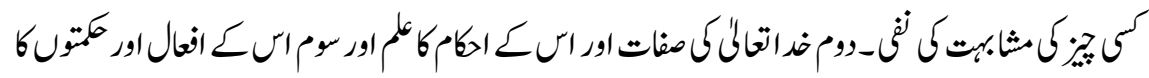

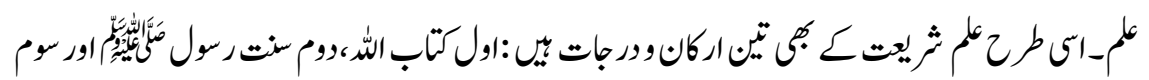

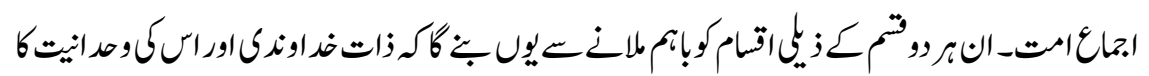

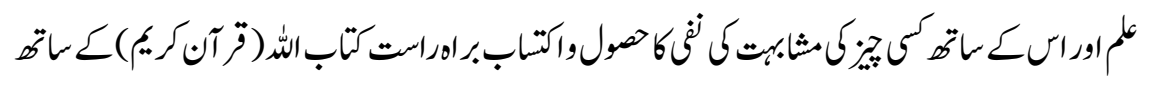

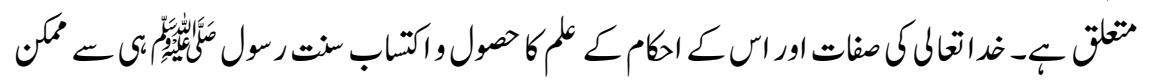

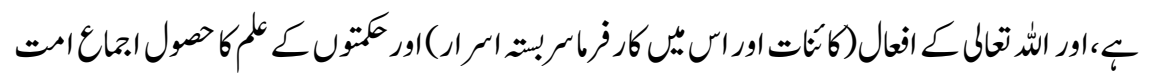

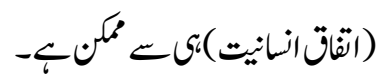

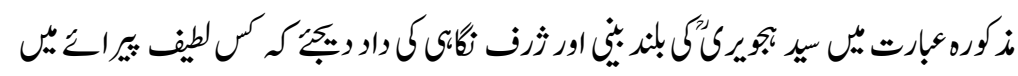

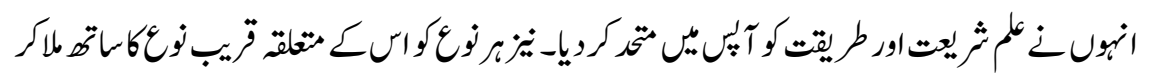

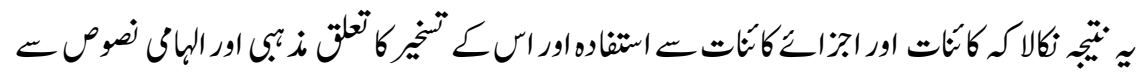

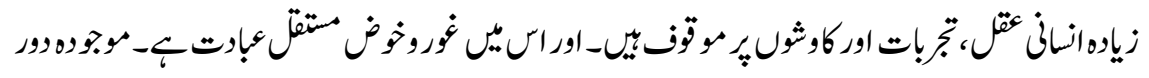

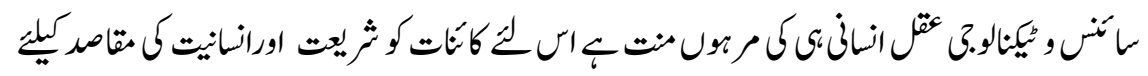

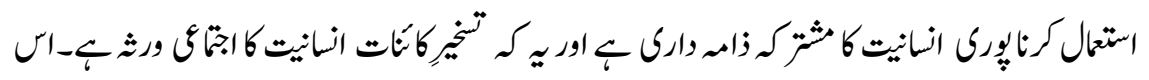

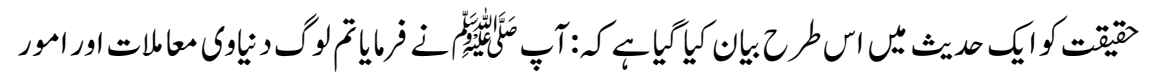

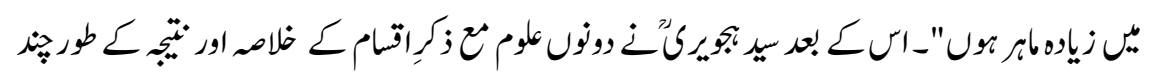

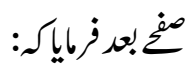


"العلوم ثلاثت: علم من الله وعلم مع الله و علم باللـعلم بالله

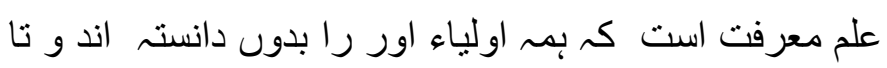
تعريف و تعرف اور نبود ايثان وى را نداستند...-الخ" 16

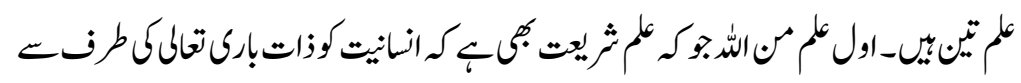

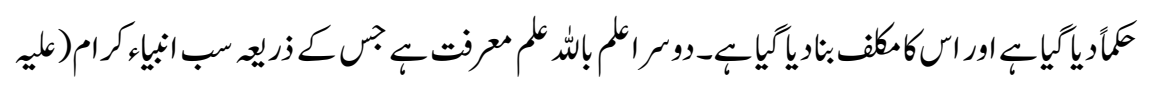

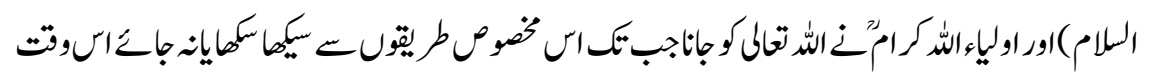

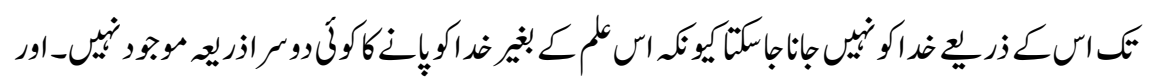

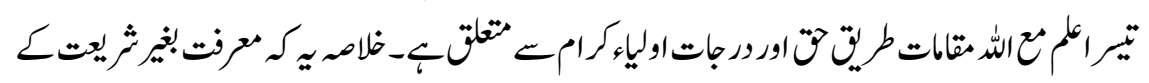

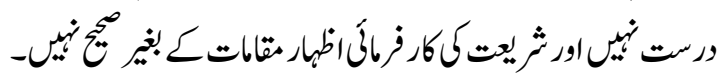

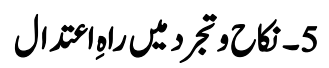

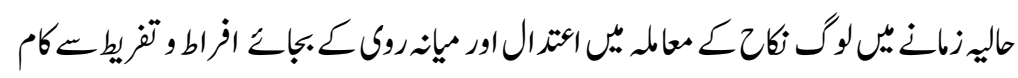

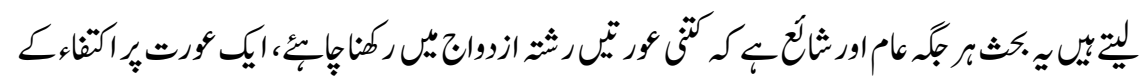

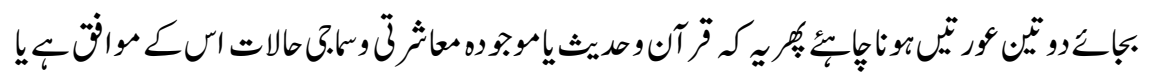

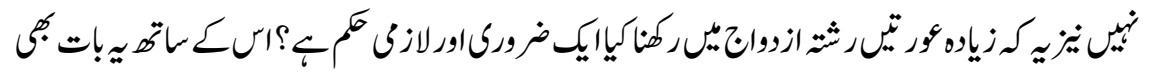

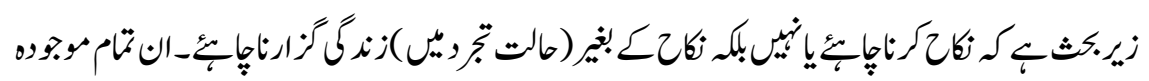

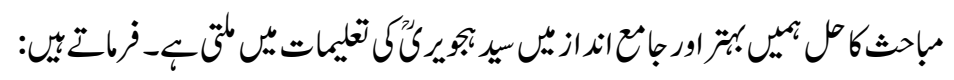

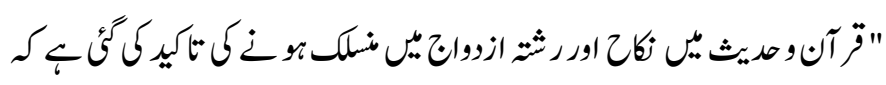

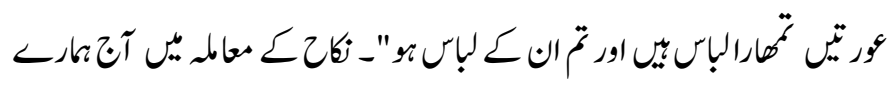

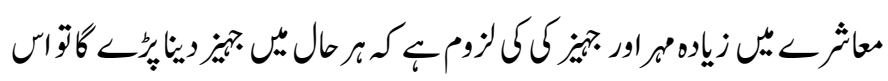

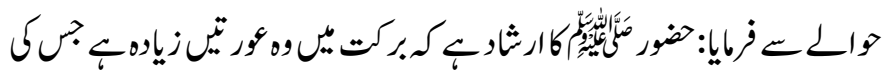

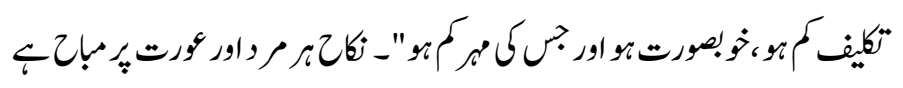

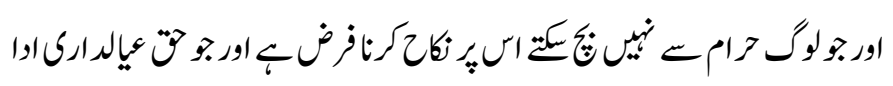

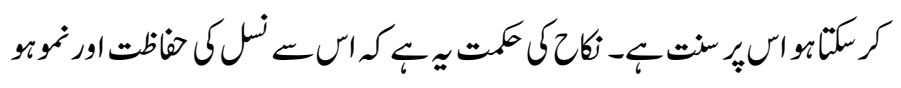




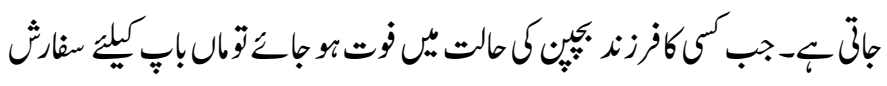

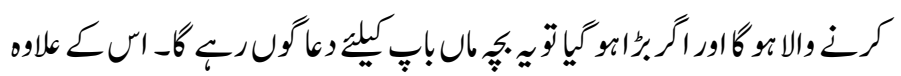

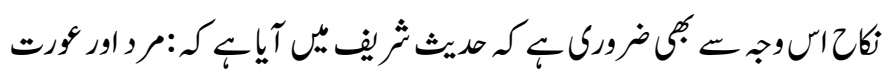

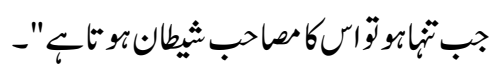

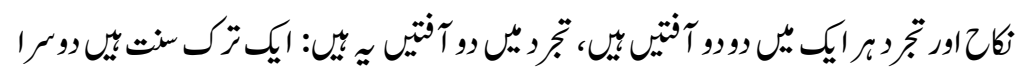

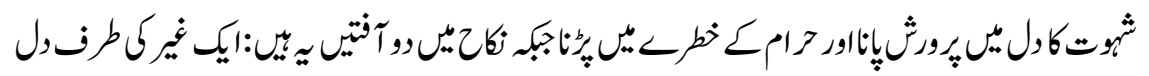

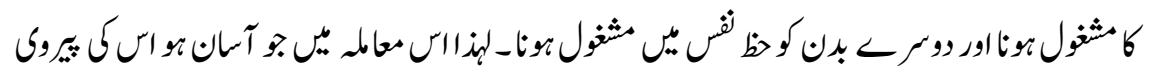

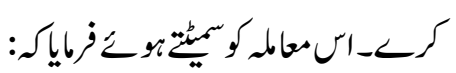

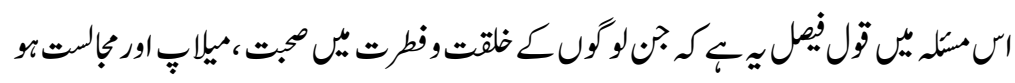

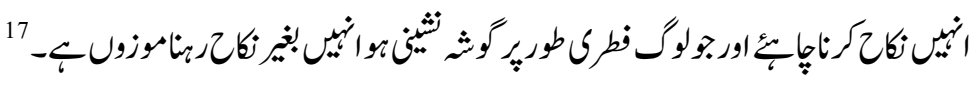

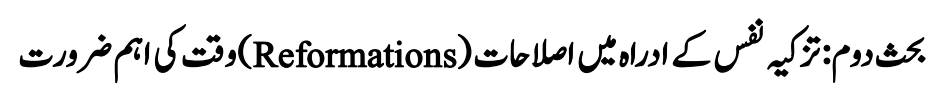

املامات

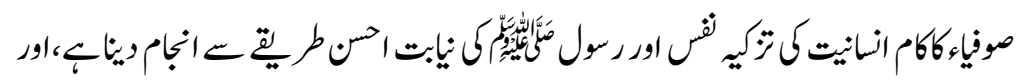

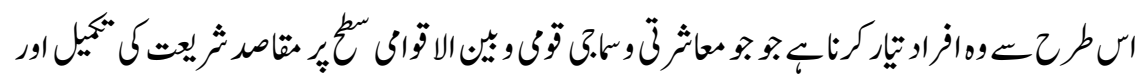

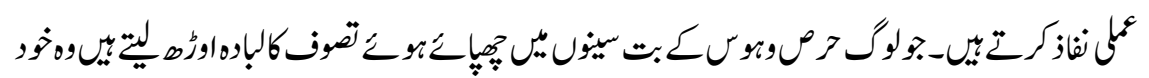

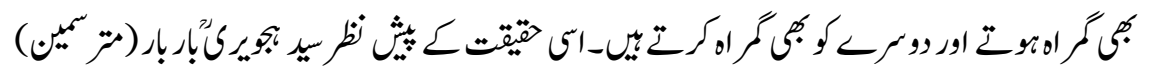

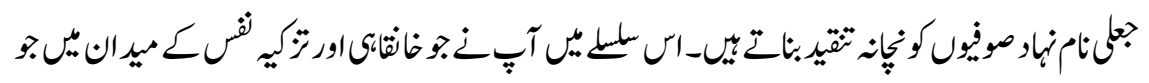

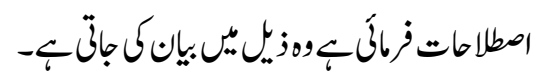

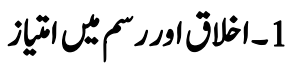

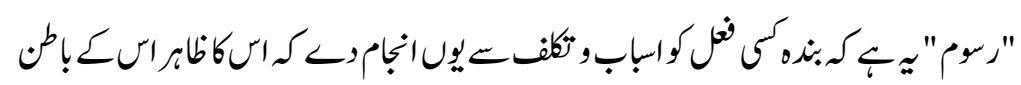

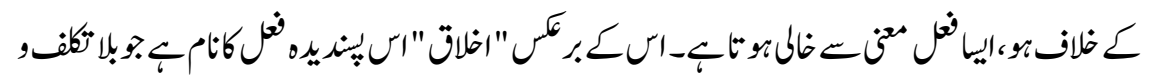

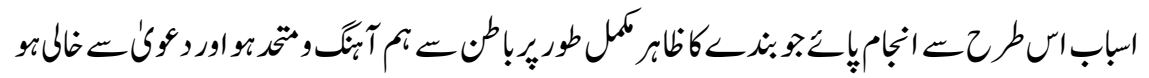




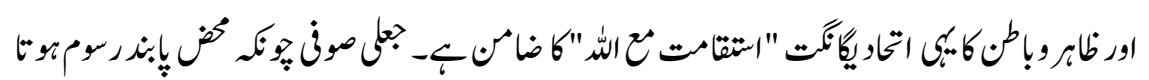

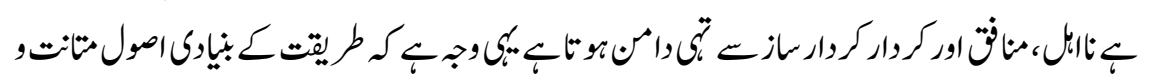

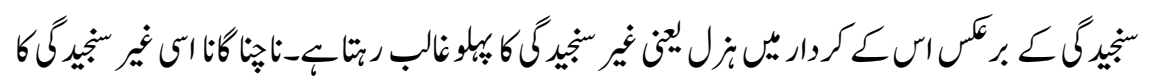

$$
{ }^{18}
$$

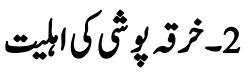

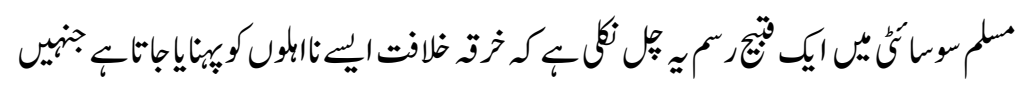

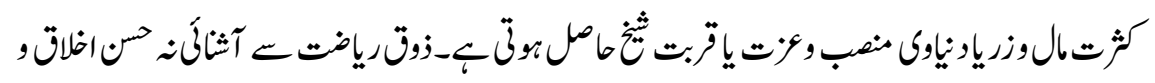

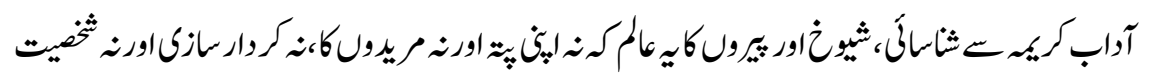

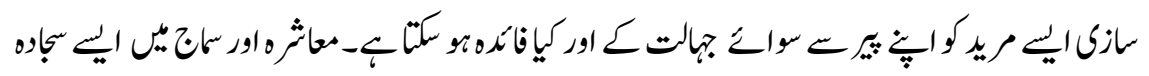

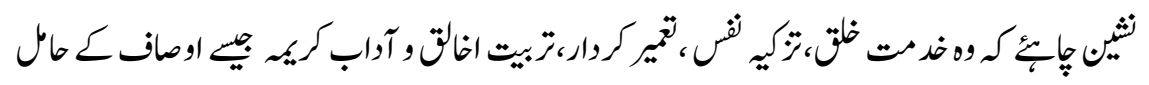

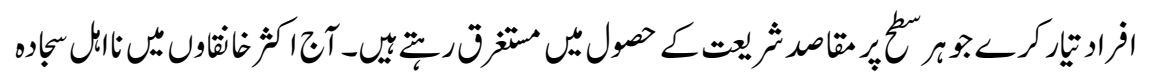

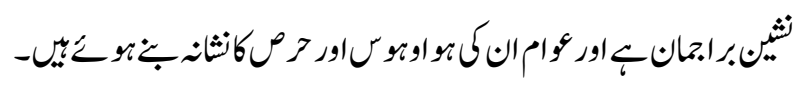

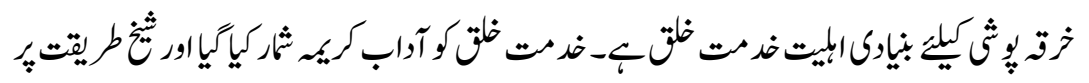

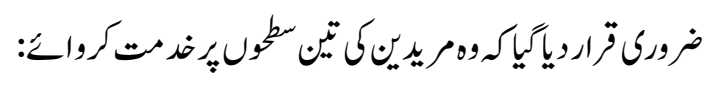

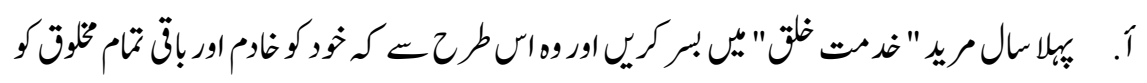

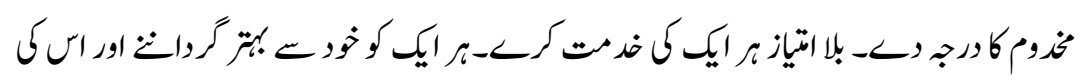

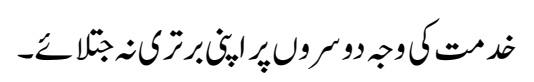

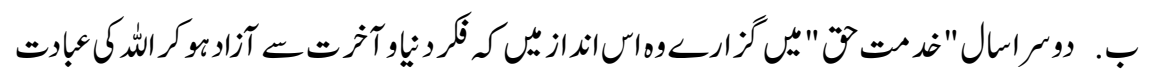

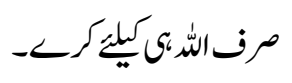

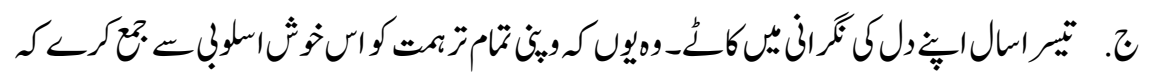

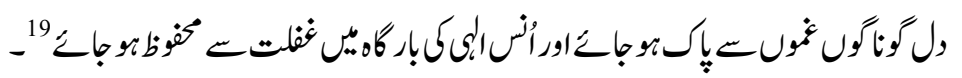

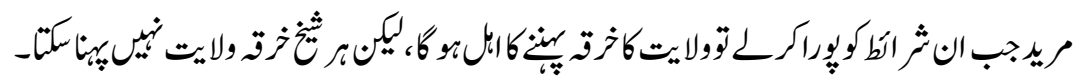

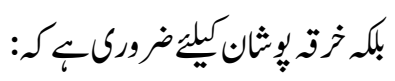




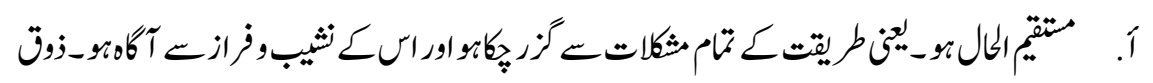

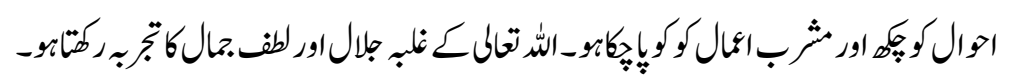

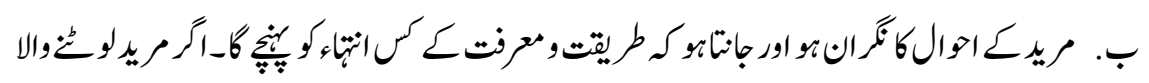

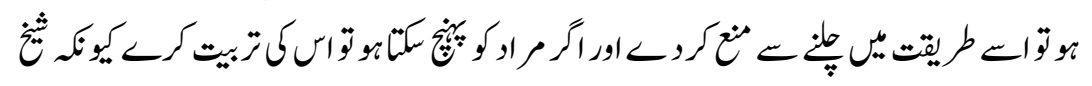

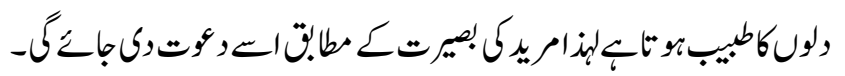

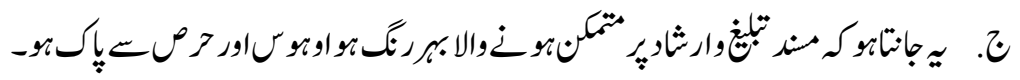

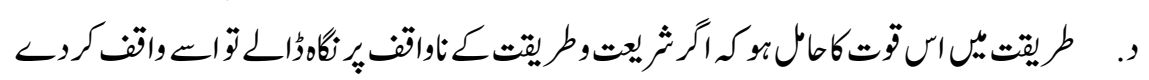

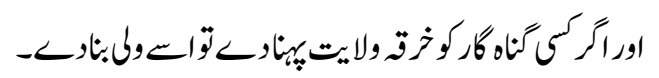

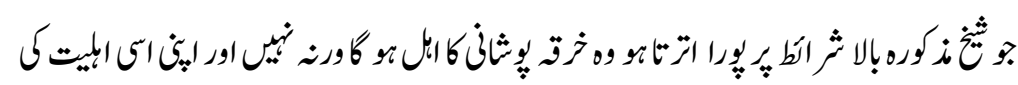

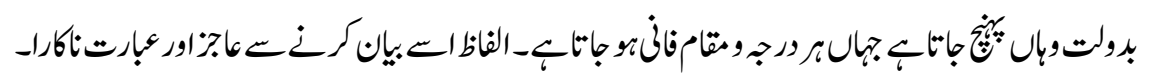

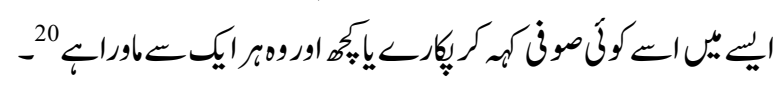

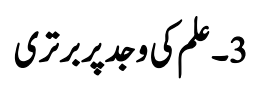

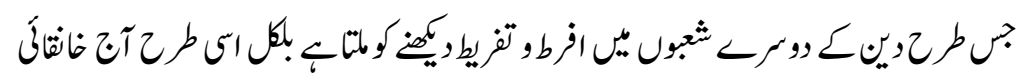

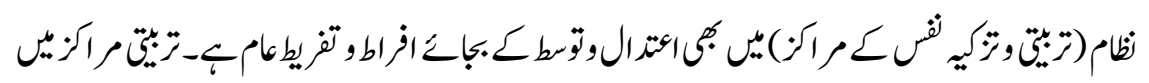

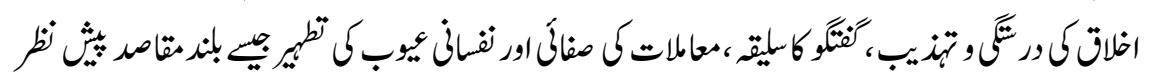

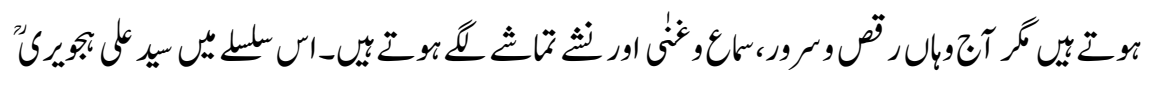

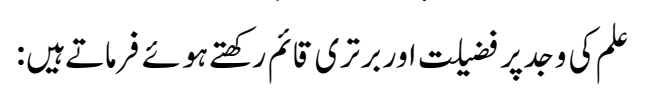

و متفق اند مشائخ رضى الله عنبم اجمعين

كي سلطان علم قوى تر بايد از سلطان

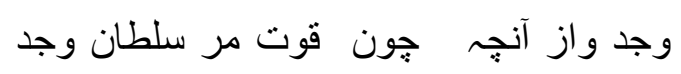

را بانثد واجد را بر محل خطر بانثد و جون آندان

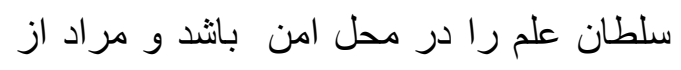




$$
\begin{aligned}
& \text { اين جمل آن است كى اندر بمه احوال بايد كـ } \\
& \text { طالب متابع علم و شر ع باشند....الخ الخ }
\end{aligned}
$$

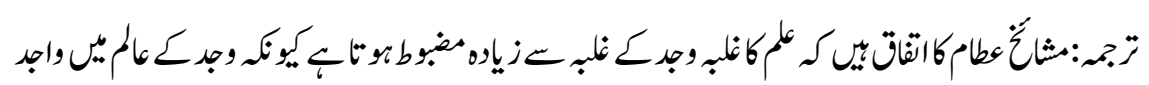

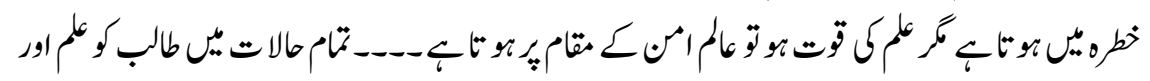

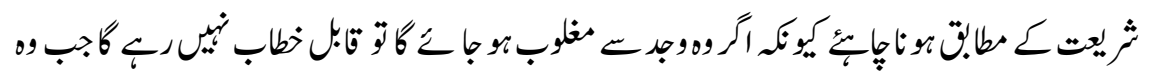

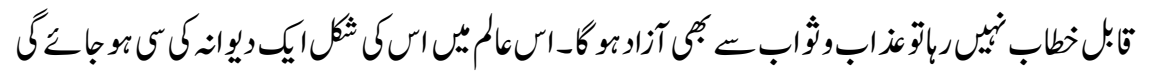

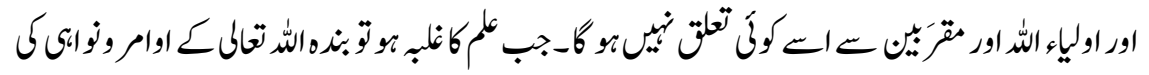

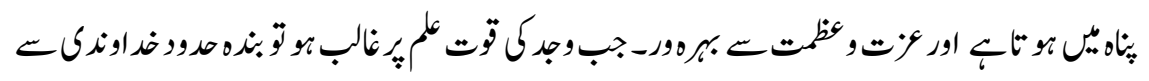

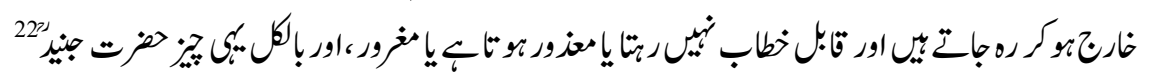

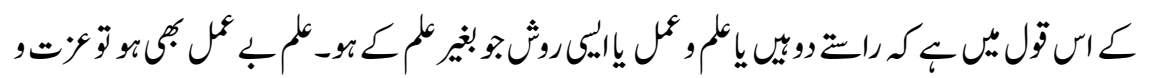

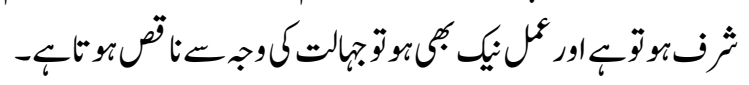

\section{4-صونكيلعلازكاوصاف}

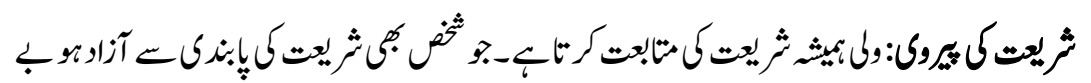

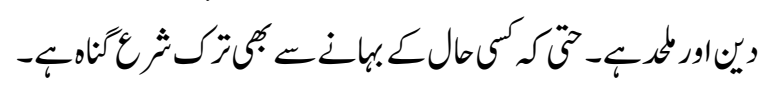

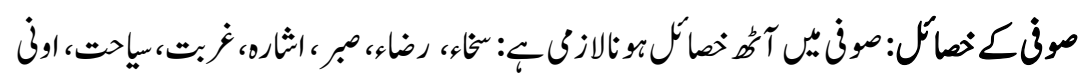

$$
\text { لباس اونتر }
$$

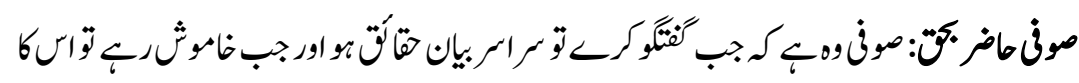

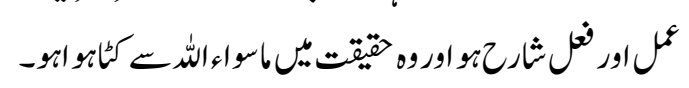

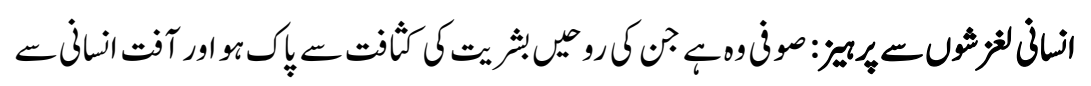

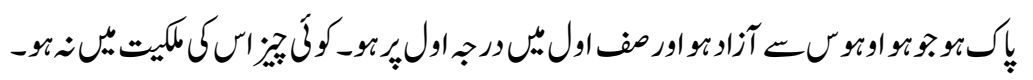

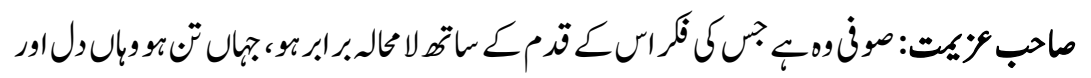

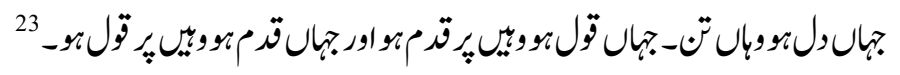

$$
\text { 5ـ جا:ل متصوف س اجثناب }
$$




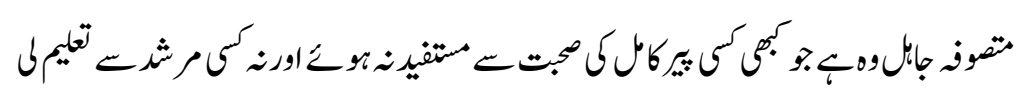

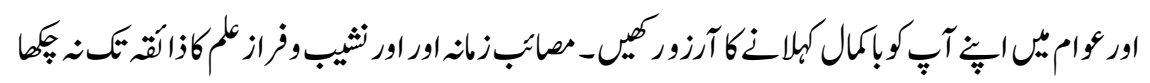

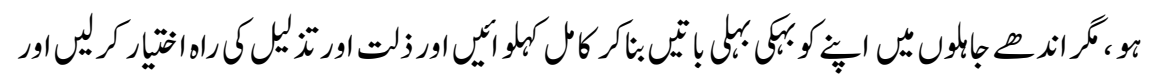

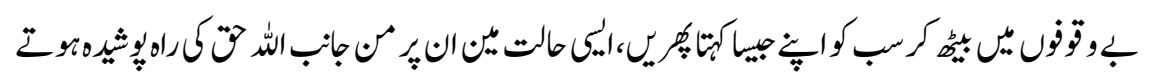

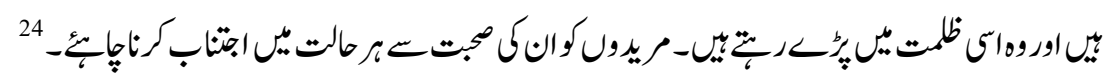

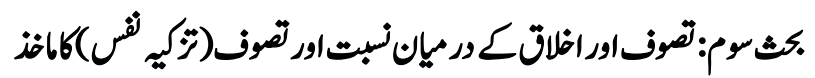

\section{الف:تصوفاخلاقعاليكانامب-}

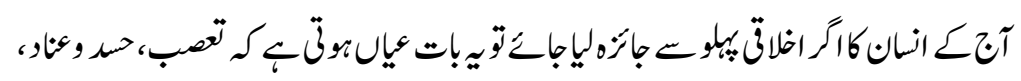

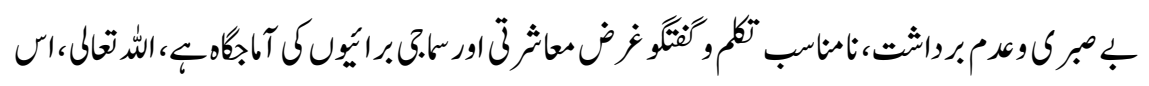

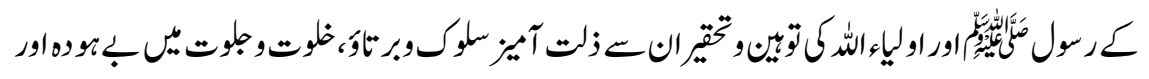

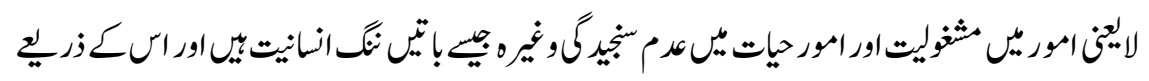

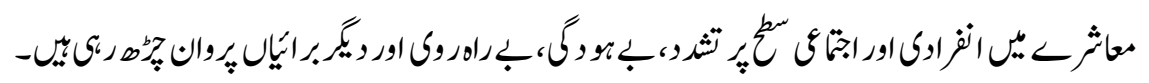

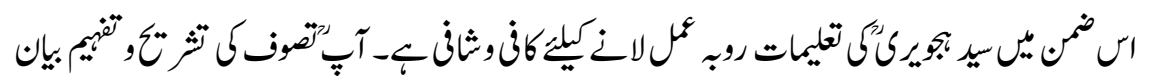

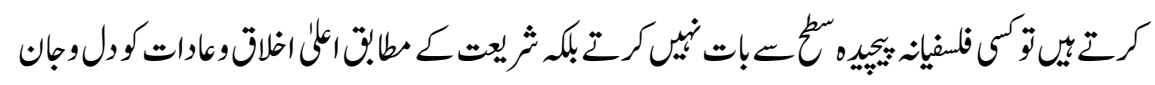

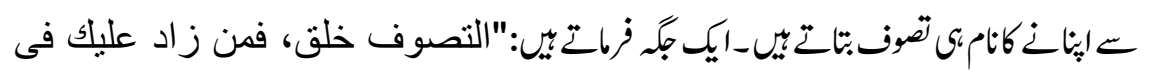

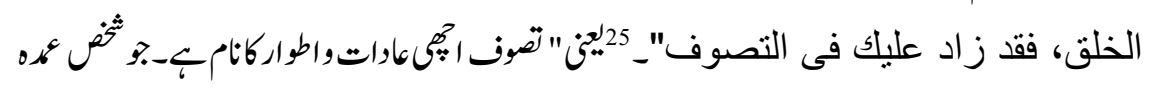

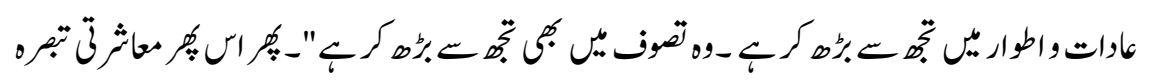

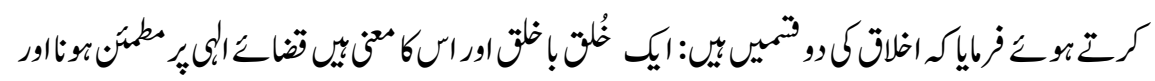

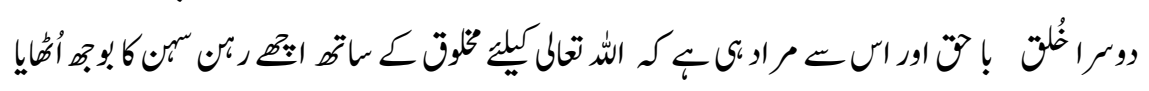

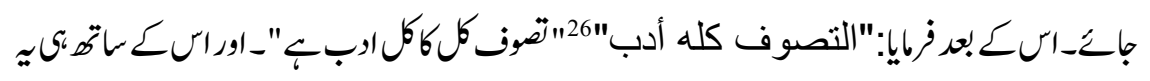

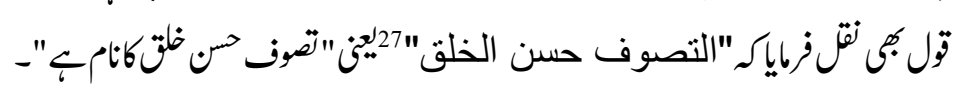

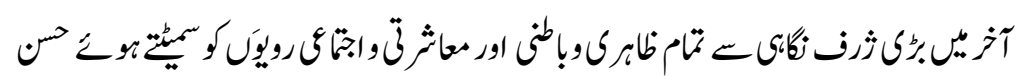

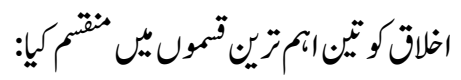




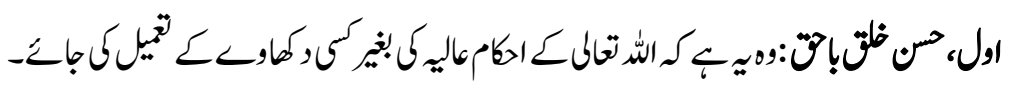

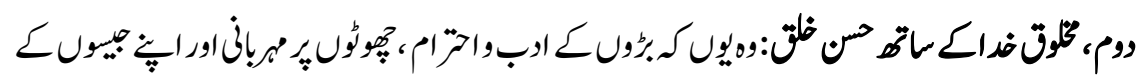

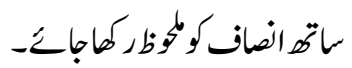

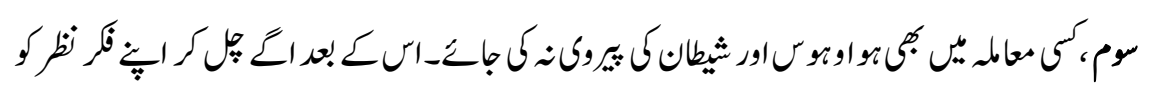

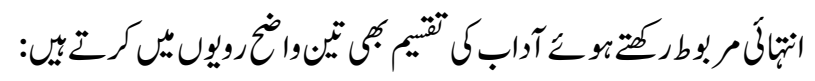

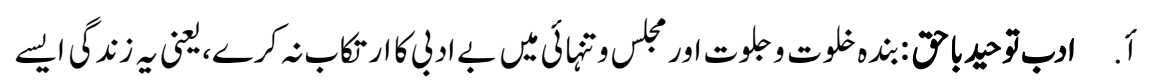

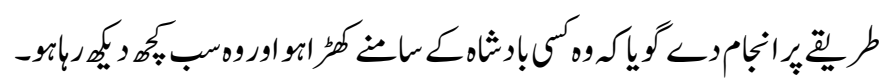

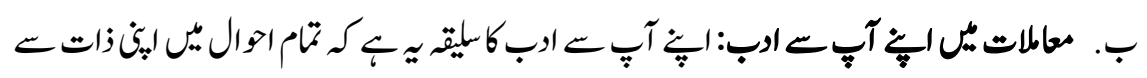

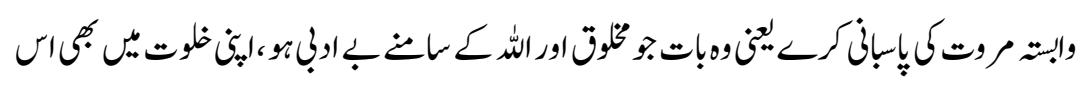

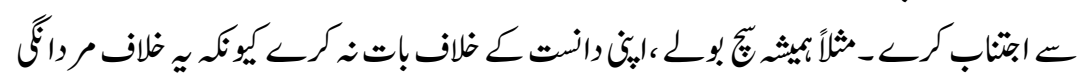

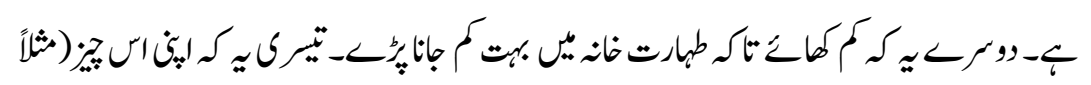

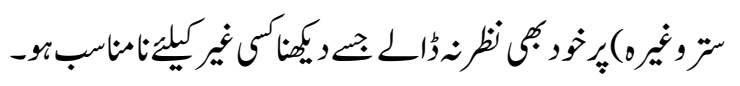

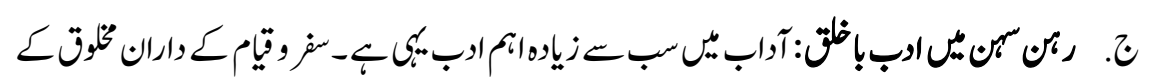

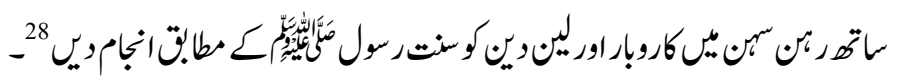

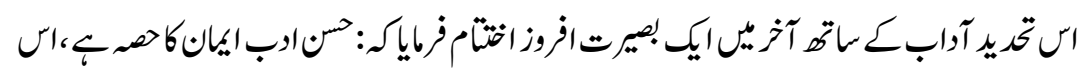

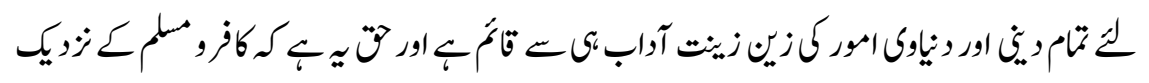

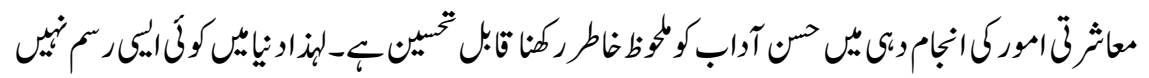

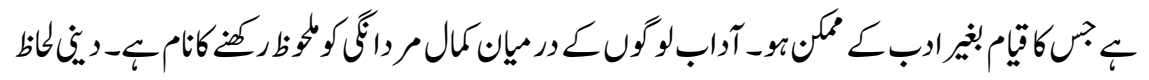

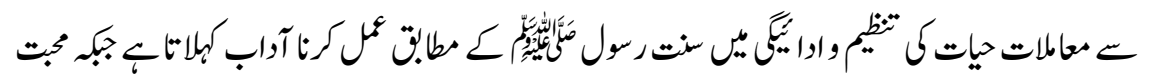

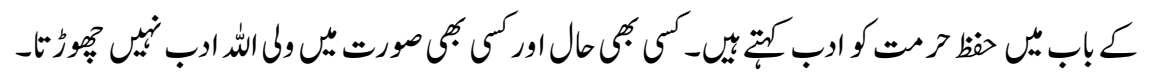

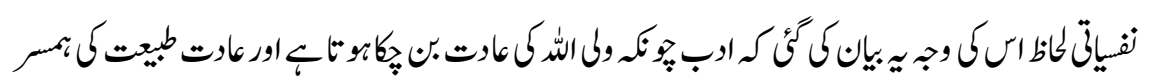

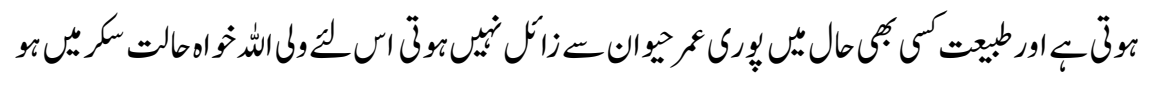




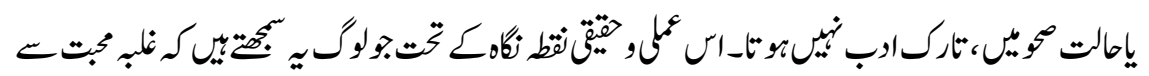

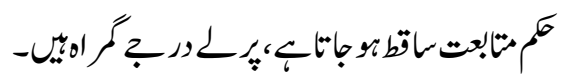

\section{ب:تزكي نسكامن}

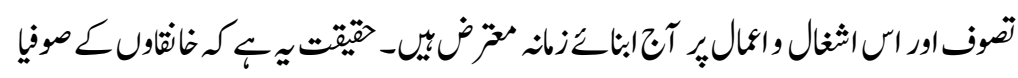

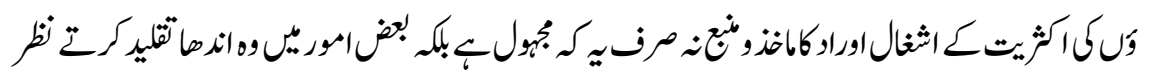

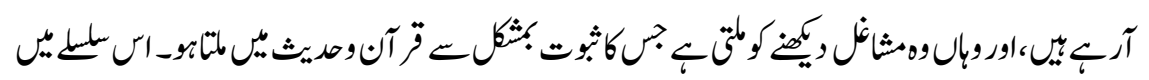

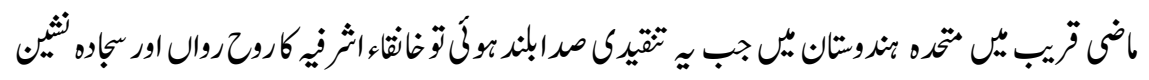

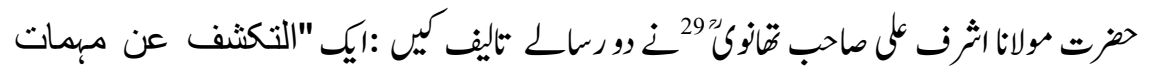

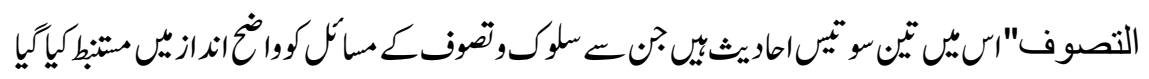

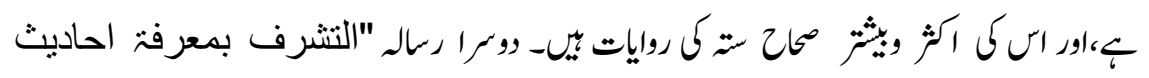

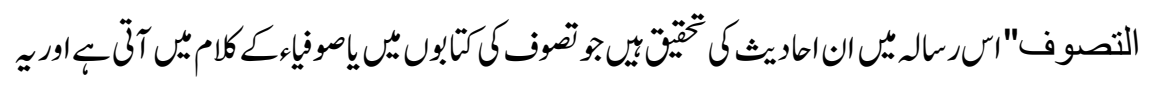

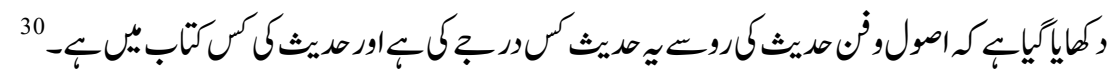

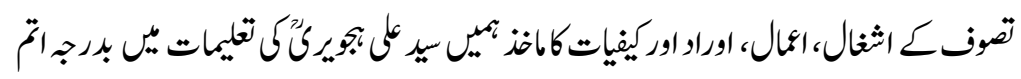

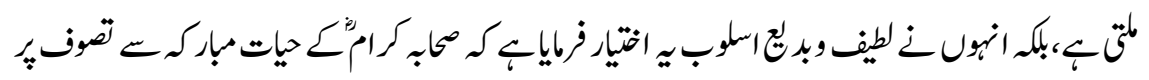

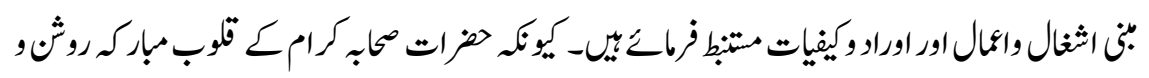

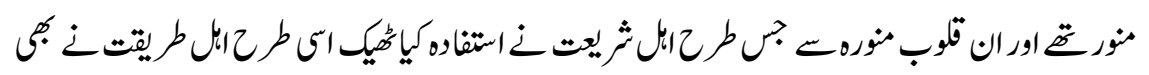

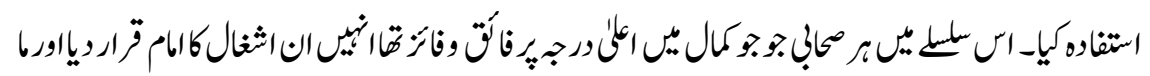

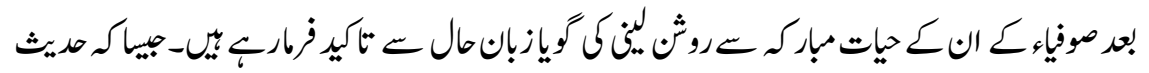

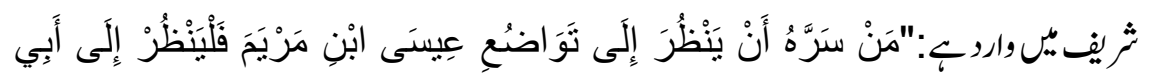

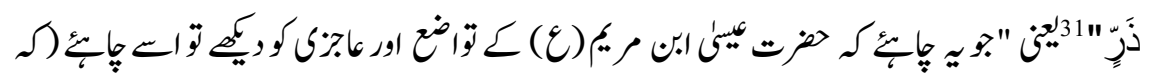

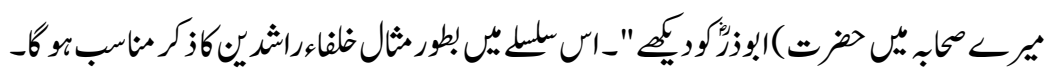

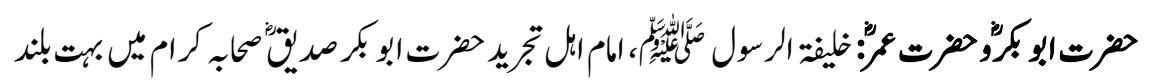

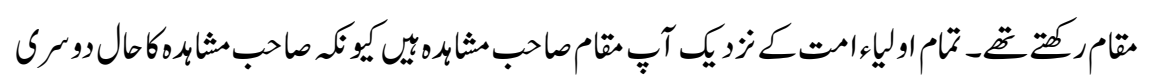




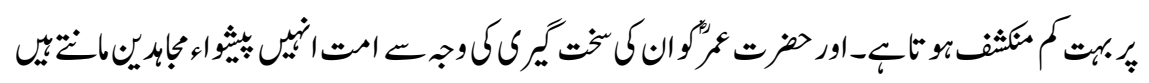

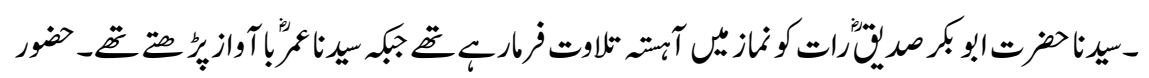

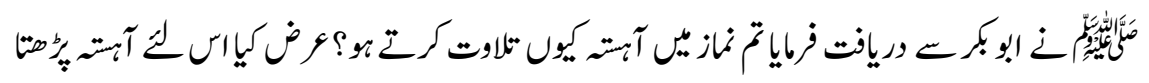

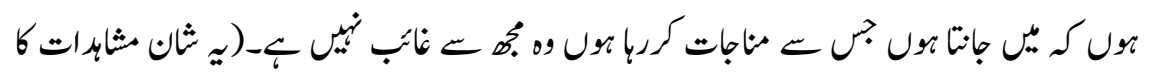

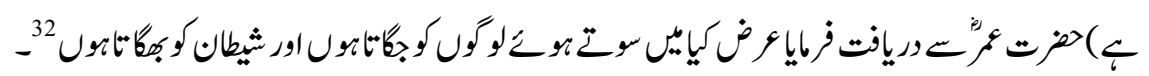
)

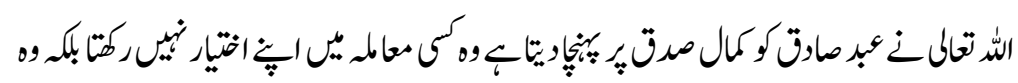

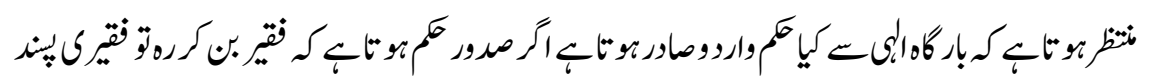

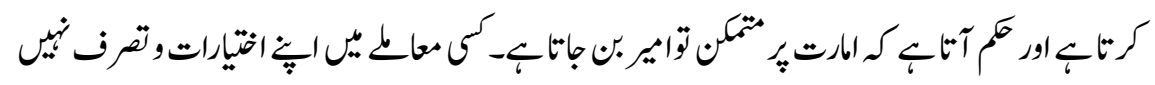

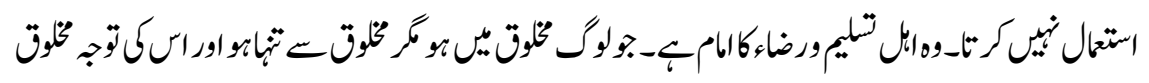

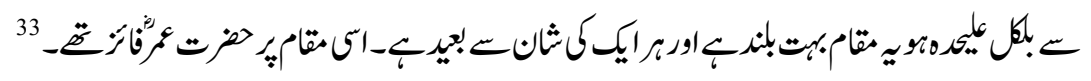

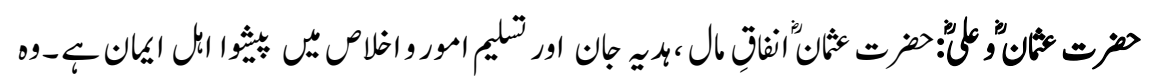

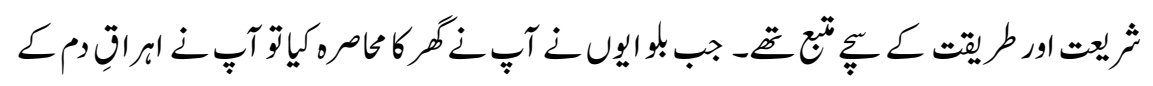

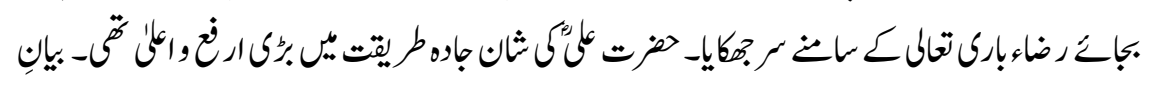

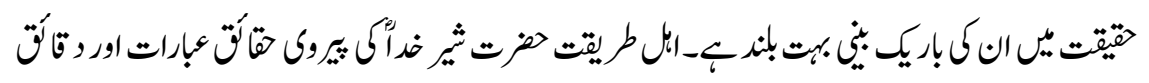

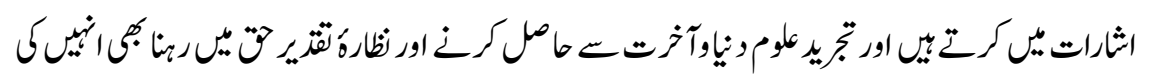

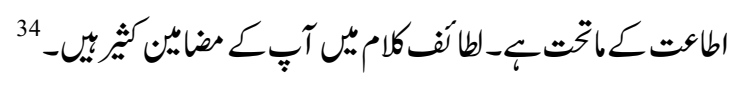

\section{فام5.كث}

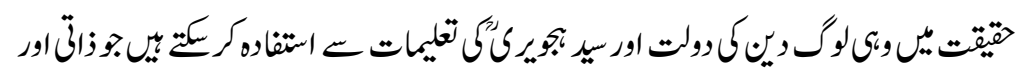

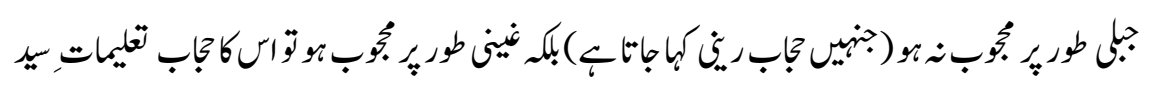

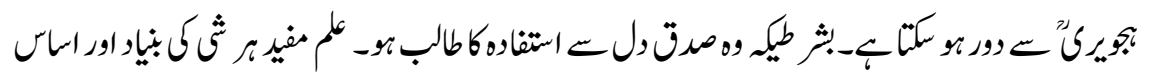

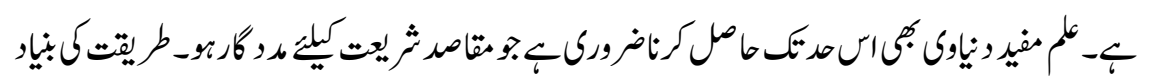

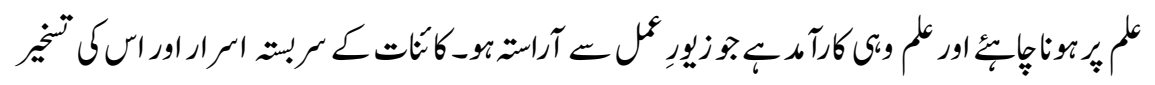




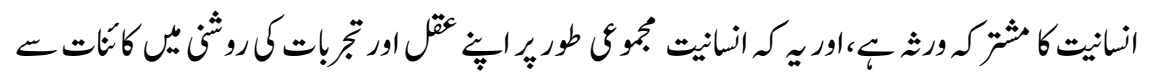

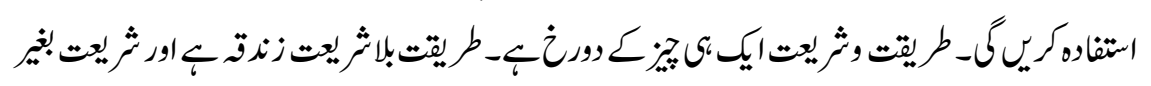

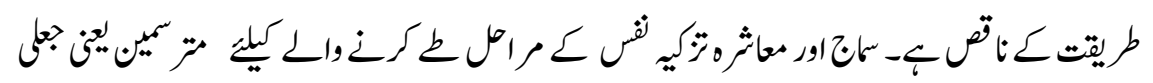

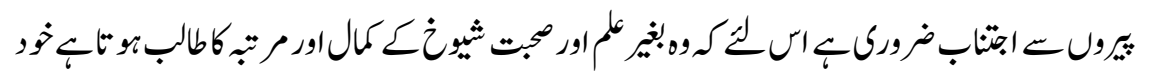

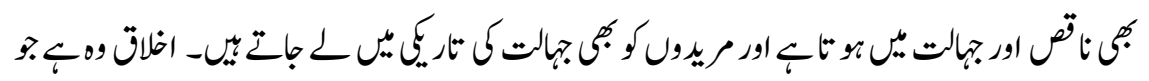

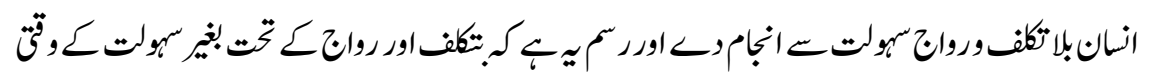

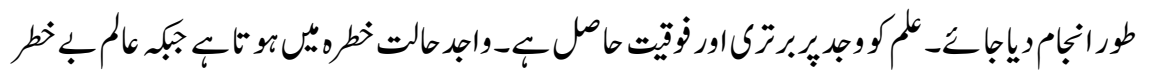

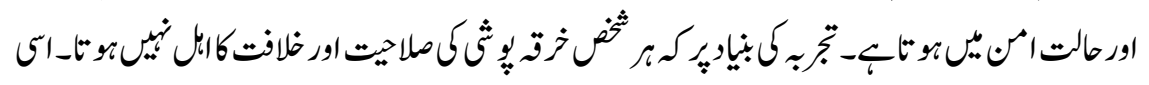

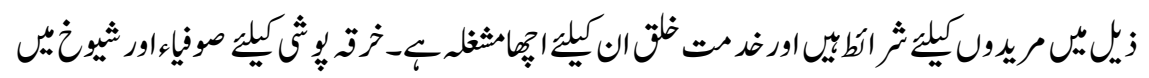

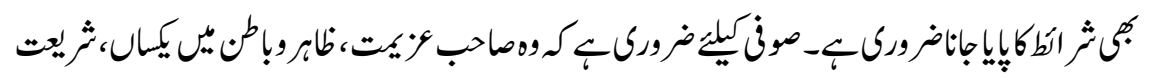

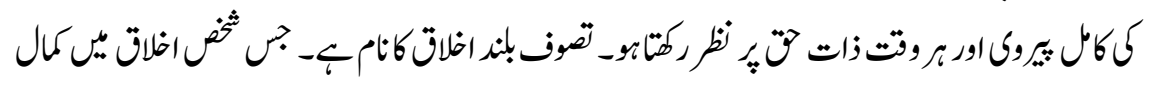

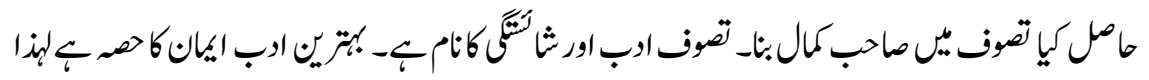

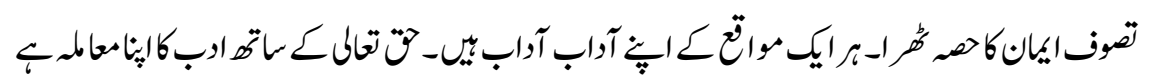

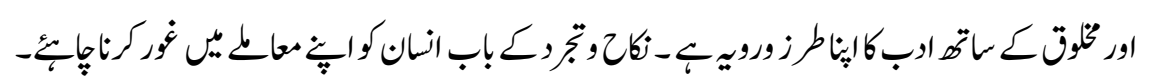

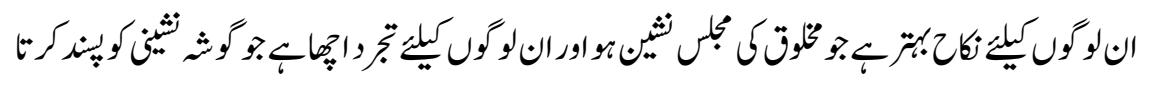

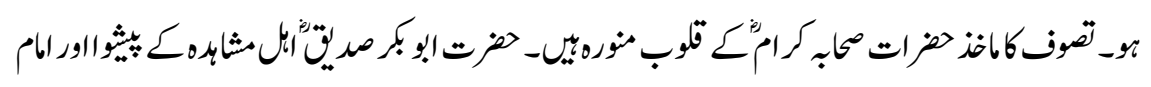

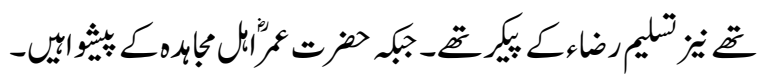

سفارثات

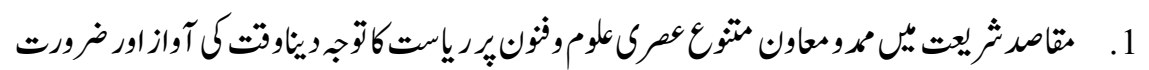

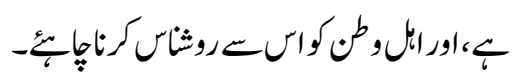

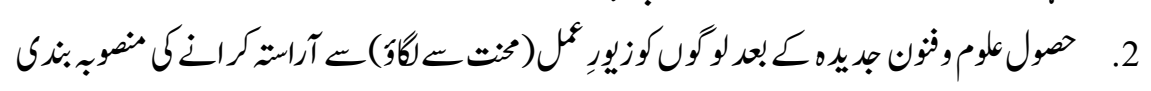

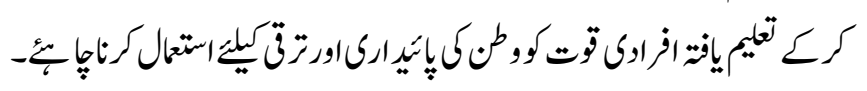




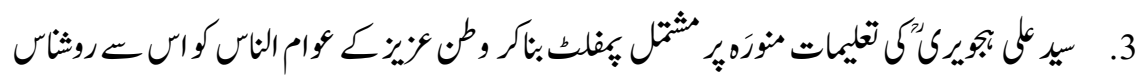

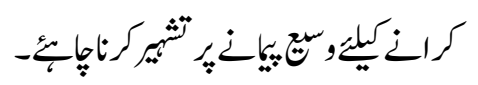

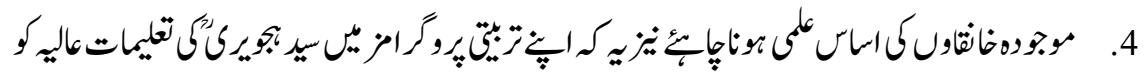

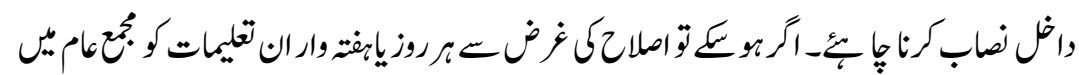

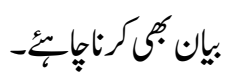

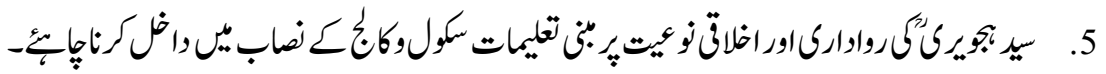
6.

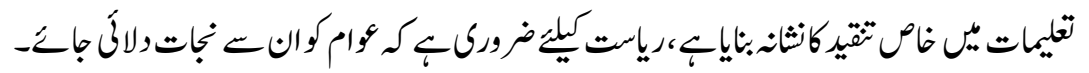

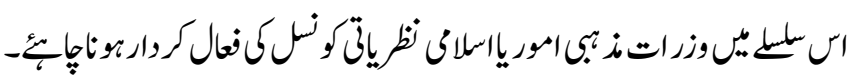
7.

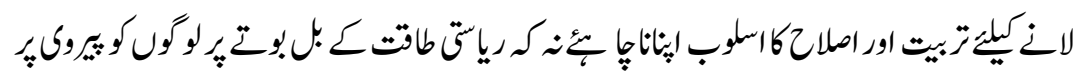
مجبوركري-

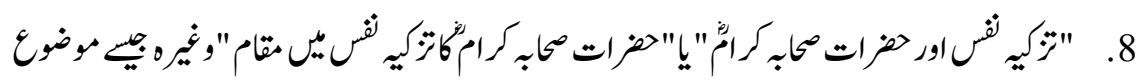

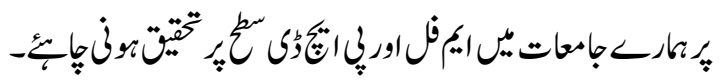

واشىووالـجات

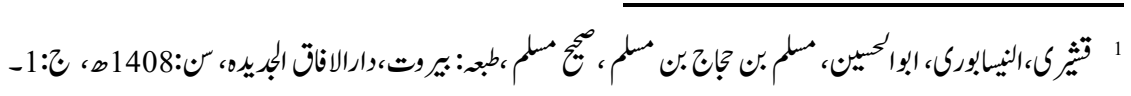
ص:36

Al-Qusharī, 'Abū al-Husain Muslim bin 'Al-Hajāj bin 'Muslīm,Sahīh ul-'Muslīm, Baīrut:Dār ul-āfaq Jadīd, 1408

2

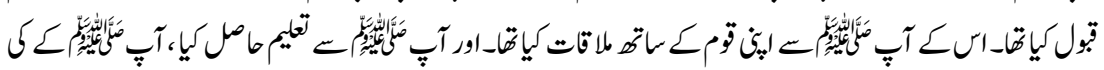

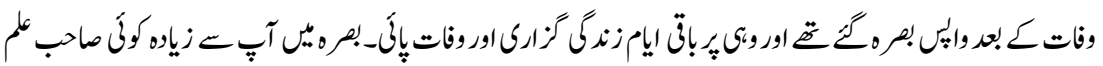

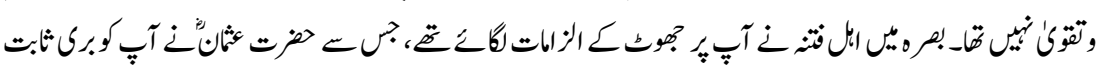

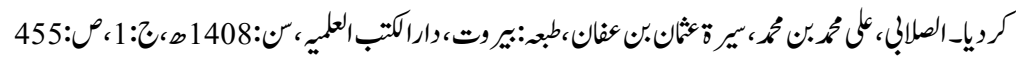


Al-Ṣalābī, 'Muhāmmad bin Muhāmmād, Seerāt Uthmān bin 'Afhān, Bāirut: Dār ulKutub-al-ilmīya, 1408

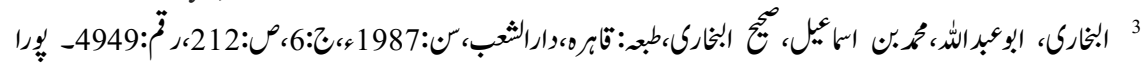

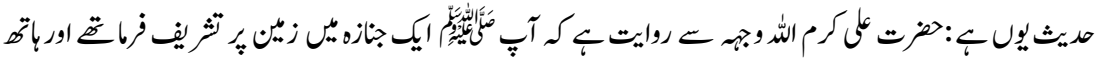

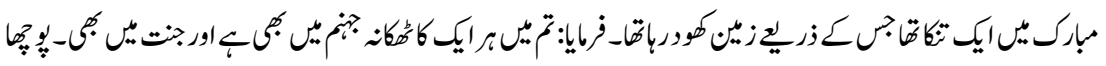

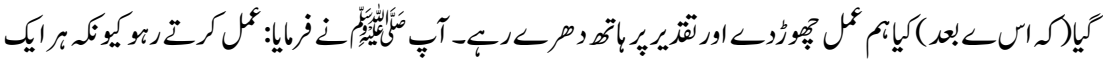

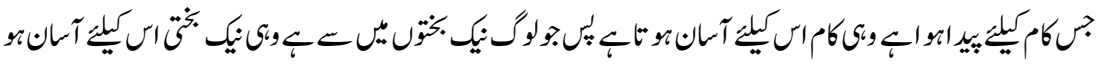

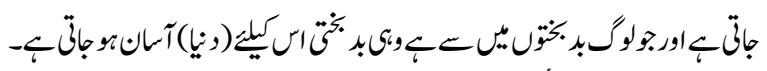

Al-Buḱhārī, 'Abū Abdullāḥ Muhāmmad bin 'Ismā‘īl, Sahīh ul-'Bukharī,: Dār ul-ṣhāb, 1987

Al-Quran, Surh Tul Bakara: 7/2.

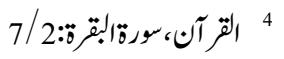

Al-Quran, Surh Tul Nahal: 108/16.

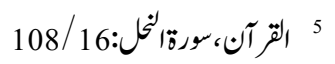

$$
6
$$

Al-Quran, Surh Tul Motaffeen: 14/83.

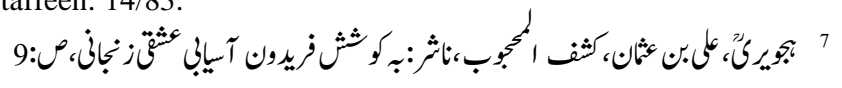

Al-Hājwarī, 'Uthmān bin 'Alī, Kashf-ul-'Mahjjob,Irān: Fāridun 'Eshqī,1960,P 9.

$$
8 \text { الترآنهورةالبقه:102/2 }
$$

Al-Quran, Surh Tul Bakara: 102/2.

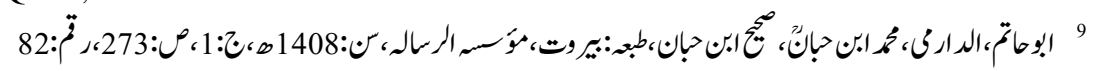

Al-Hātīm, Al-dārmī, 'Muhāmmad bin hībāān, Sahīh Ibinī- hībāān, Baīrut: MuwașīsūRīsālh 1408

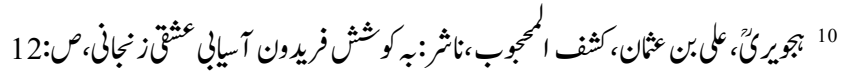

Al-Hājwarī, 'Uthmān bin 'Alī, Kashf-ul-'Mahjob,Irān: Fāridun 'Eshqī,1960,P 12

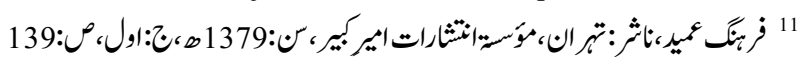

Farhāng-e-āmīd, 'Irān ,tahrān: Muwașīsū-intishrāt-e-Amīr-e-Kābīr, 1379

$$
12
$$

Ibid, Vol 2, P 111.

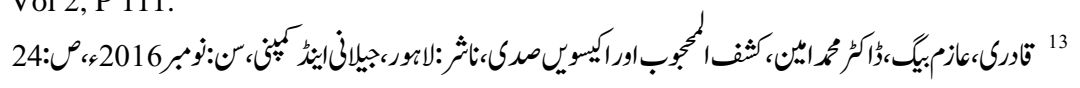

Al-Qusharī, 'Asīm Baig, Kashful-Maḥjob aor Ikīisw-e-Ṣādī, Lahor: Jīlanī ānd company,2016

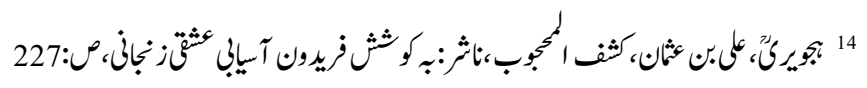

Al-Hājwarī, 'Uthmān bin 'Alī, Kashf-ul- 'Mahjob,Irān: Fāridun 'Eshqī,1960,P 227.

15 ن نمصردساتق،ص:13 
Ibid, P 13.

16 ن نمصردساتّ،ص:15

Ibid, P 15.

Ibid, Bab Adabhm Fe Altazweej waltajreed, P 216.

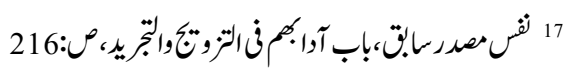

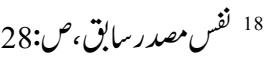

Ibid, P 28.

Ibid, P 15.

19 ن ن مصدرساتق،ص:15

Ibid, 34 .

20 - ن نمصردماتق،ص:34

Ibid, P 246.

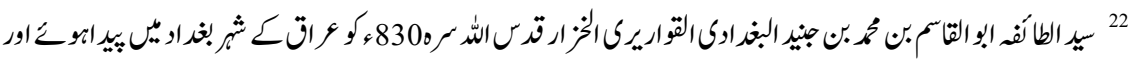

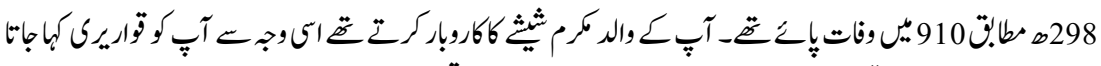

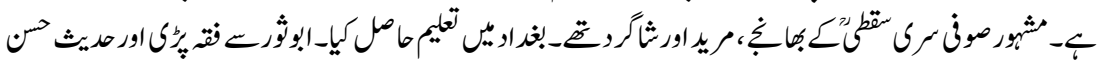

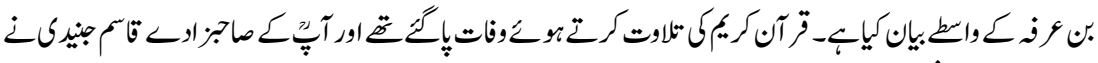

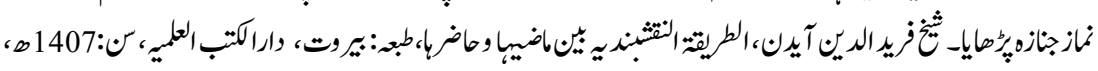

ن: 1: ص: ص:449

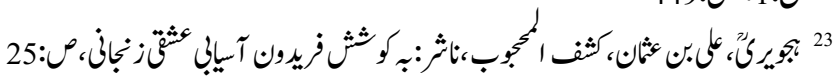

Al-Hājwarī, 'Uthmān bin 'Alī, Kashf-ul-'Maḥjob,Irān: Fāridun 'Eshqīi,1960,P 25.

24

Ibid, P 28.

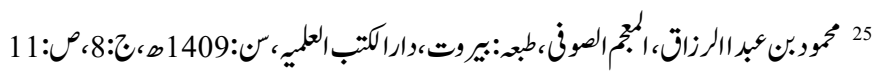

Muhāmod bin 'Abdū-r āzāq, Al-'Mujām-u-Șofî, Baīrut: Dār ul-Kutub-al-ilmīyā, 1408

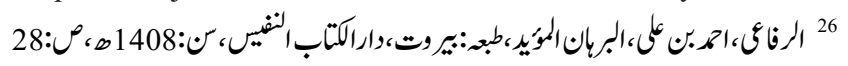

Al-Rīfāhī, 'Ahmād bin 'Alī, Al- 'būrhān-ul-Mūayīd, Baīrut: Dār ul-Kībat-ul-nafees, 1408

Ibid.

$$
28
$$

Al-Hājwarī, 'Uthmān bin 'Alī, Kashf-ul-'Maḥjob,Irān: Fāridun 'Eshqīi,1960,P 28.

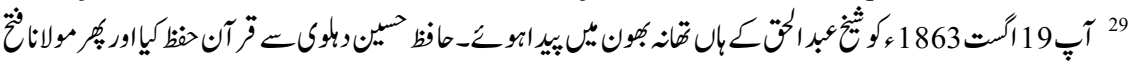

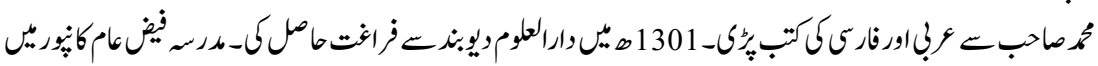

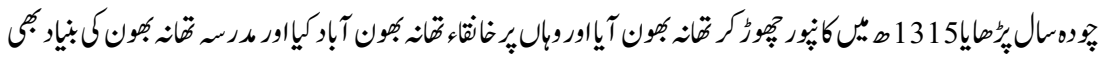




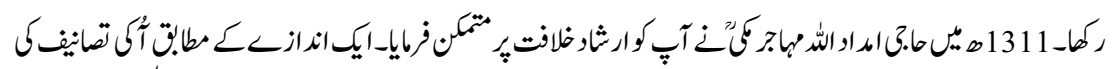

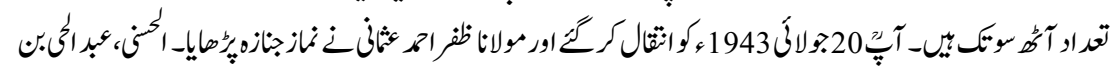

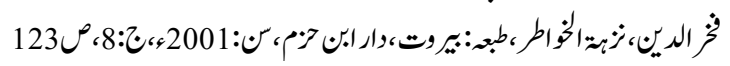

Al-Hāsanī, 'Abd-ūl-Hayī, Fakhr-u dīn, Nushāt-ūl-Khwatīr, Baīrut: Dār ībn-e-hazm, 2001

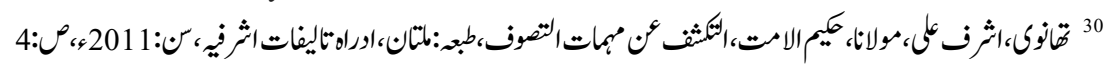

Al-Tānwī, 'Ashrāf 'Alī, Al-'Takāshuf-en'Muhāmt-u-Tāwuf, Multan: Idārah Tālīfat-e'Ashrāfìya,2011

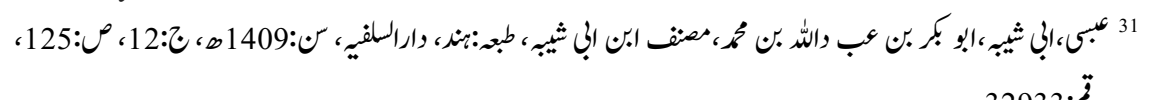

$$
\text { رقم:32933 }
$$

Al-Abasī, 'Abū bākr bin Abdullāḥ, 'Musānif-Ibni Abi Shaibā, Hind: Dār-ul-sālāfĩyā, 1409

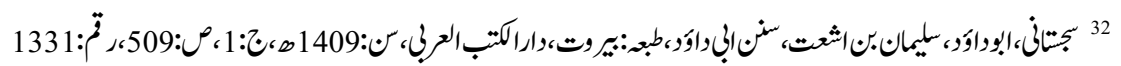

Al-Sajīstān̄i, 'Sulā̄mān bin āshath Sunan-e-Abī- Dāwood, Baīrut: Dār-ul-kutab ālarbīyā, 1409

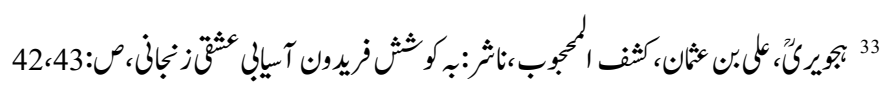

Al-Hājwarī, 'Uthmān bin 'Alī, Kashf-ul-'Maḥjob,Irān: Fāridun 'Eshqī,1960,P 42,43.

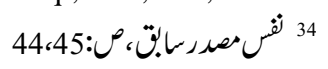

Ibid, P 44,45. 